\title{
PUBLICACIONES SOBRE FILOLOGÍA INGLESA EN ESPAÑA (2011)
}

\section{RESUMEN}

Bibliografía relativa a Filología Inglesa publicada en España en 2011.

PalabRas Clave: Filología Inglesa; bibliografía; España.

\section{Abstract}

Bibliography on English Studies published in Spanish, 2011.

KEY WORDS: English Studies; bibliography; Spain.

ÍNDICE GENERAL
A. Literatura inglesa e irlandesa
B. LiterATURA NORTEAMERICANA
C. Otras literaturas en Lengua INGLesa
D. ENFOQUES TEÓRICOS O GENERALISTAS
E. Traducción
F. Cultura y Cine 


\section{A. LITERATURA INGLESA E IRLANDESA}

DíDAC LloRENS CUBEDO

UNED. Madrid

dllorens@flog.uned.es

ÍNDICE

1. Literatura anglosajona, medieval y renacentista

2. Restauración y siglo XVIII

3. Siglo XIX

4. Siglo xx y época contemporánea

\section{Literatura Anglosajona, Medieval y Renacentista}

Alonso Navarro, José Antonio. «El Purgatorio de San Patricio (Sir Owain), de Henry of Saltrey: Apuntes generales». Oceánide 3 (2011). Revista electrónica.

BANDín Fuertes, Elena. «Performing Shakespeare in a Conflicting Cultural Context: Othello in Francoist Spain». SEDERI 21 (2011): 119-132.

Bradshaw Busbee, Mark. «The Idea of India in Early Medieval England». India in the World. Eds. Cristina Gámez-Fernández y Antonia Navarro-Tejero. Newcastle upon Tyne: Cambridge Scholars Publishing, 2011. 3-16.

CERDÁ, Juan F. «Shakespeare in García Lorca’s Early Poems». Atlantis. Journal of the Spanish Association of Anglo-American Studies 33.1 (2011): 33-52.

CinPoEs, Nicoleta. «Defrauding Daughters Turning Deviant Wives? Reading Female Agency in The Merchant of Venice». SEDERI 21 (2011): 133-146.

Crummé, Hannah Leah. «The Impact of Lord Burghley and the Earl of Leicester's SpanishSpeaking Secretariats». SEDERI 21 (2011): 7-27.

Demetriou, Eroulla y Ruiz Mas, José. Get Thee to a Playhouse! An Introduction to Elizabethan and Shakespearean Drama for Young Students of Literature. Jaén: Servicio de Publicaciones de la Universidad de Jaén, 2011.

Domínguez Romero, Elena. «Reading the 'Helicon Collage': Hidden Stories in the Collected Fragments». Miscelánea: A Journal of English and American Studies 44 (2011): 13-32.

Gleeson Ó Tuathaigh, Jean. «Resolución Varonil or the Manly Resolve of Countess Mary Stuart O’Donnell». Estudios Irlandeses 6 (2011): 83-90.

Gregor, Keith y BAndín, Elena. «The Role of the Censor in the Reception of Shakespearean Drama in Francoist Spain: The Strange Case of The Taming of the Shrew». Censorship across Borders: The Reception of English Literature in Twentieth-Century Europe. Eds. Catherine O'Leary y Alberto Lázaro. Newcastle upon Tyne: Cambridge Scholars Publishing, 2011. 143-160.

Gregor, Keith y Pujante, Ángel-Luis. Macbeth en España. Las versiones neoclásicas. Murcia: Editum, 2011.

Hickman, Alan F. «In a Minor Key: Visual Effects in Shakespeare's Sonnets». SEDERI 21 (2011): 147-161. 
Hoenselaars, Ton. «The Company of Shakespeare in Exile: Towards a Reading of Internment Camp Cultures». Atlantis. Journal of the Spanish Association of Anglo-American Studies 33.2 (2011): 89-103.

Jarazo Alvarez, Rubén y Domínguez Romero, Elena. «Breaking Boundaries and Dislocating Myths in Alvaro Cunqueiro's Función de Romeo e Xulieta, Famosos Namorados (1956): A Galician Adaptation of Shakespeare's Romeo and Juliet in the 20th Century». ES: Revista de Filología Inglesa 32 (2011): 179-202.

Oncins MarTínez, Hannah Leah. «Shakespeare and Chess Again: A Proposal for an Alternative Reading of 'Pawn(s)' in King Lear, King John and The Winter's Tale». SEDERI 21 (2011): $29-48$.

OrKIN, Martin. «Film and the Uncanny, Shakespeare Making Possible Things Not So Held, Communicating with Dreams». SEDERI 21 (2011): 49-70.

Paravano, Cristina. «The Space of Identity and the Identity of Space in The City Wit by Richard Brome». SEDERI 21 (2011): 71-90.

SELL, Jonathan P. A. «Learning to Scrawl: the Evolutionary Strain in Titus Andronicus». SEDERI 21 (2011): 91-116.

\section{Restauración y Siglo XVIII}

Blanco Vacas, Jorge R. «Communicative Strategies in the Restoration Stage: Politically Allusive Prologues and Epilogues of the Popish Plot Period». A View from the South: Contemporary English and American Studies. Eds. José R. Ibáñez Ibáñez y José Francisco Fernández Sánchez Almería: Editorial Universidad de Almería, 2011. 245-251.

Borham Puyal, Miriam. «The Quixote as Literary and Political Alien in the English Antijacobin Novel: 'your wines are as foreign as your sentiments'». 1616. Anuario de la Sociedad Española de Literatura General y Comparada 1 (2011): 111-132.

DíAz Bild, Aída. «Elizabeth Hamilton's Celebration of the 'Cheerful, Pleased Old Maid'». A View from the South: Contemporary English and American Studies. Eds. José R. Ibáñez Ibáñez y José Francisco Fernández Sánchez Almería: Editorial Universidad de Almería, 2011. 9-28.

— «The Fall of the Dutiful Daughter or the Journey Without Return». Odisea: Revista de Estudios Ingleses 12 (2011): 77-96.

Figueroa Dorrego, Jorge. «Aphra Behn's Appropriation of the Literary Figure of the Jilt». Aphra Behn and Her Female Successors. Ed. Margarete Rubik. Viena: Lit Verlag, 2011. 93-107.

Haywood, Eliza. A dama solitaria e Fantomina. Trad. M. ${ }^{a}$ Fe González Fernández, intro. Jorge Figueroa Dorrego. Santiago de Compostela: Sotelo Blanco y Xunta de Galicia, 2010.

Huertas Abril, Cristina. "The Warwickshire Circle' a través de la correspondencia de Lady Luxborough: estudio y traducción de las cartas». Alfinge: Revista de Filología 23 (2011): 107-128.

Lasa Álvarez, Begoña. «Regina Maria Roche, an Eighteenth-Century Irish Writer on the Continent and Overseas». Glocal Ireland: Current Perspectives on Literature and the Visual Arts. Eds. Marisol Morales Ladrón y Juan F. Elices Agudo. Newcastle upon Tyne: Cambridge Scholars Publishing, 2011. 51-61.

Lorenzo Modia, María Jesús. «Education for Women in the Eighteenth-Century Periodical: Charlotte Lennox's The Lady's Museum». Estudios de Mujeres. Volumen VII: Diferencia, (des)igualdad y justicia. Differences, (In)equalities and Justice. Eds. Ana Antón-Pacheco Bravo, Isabel Durán Jiménez-Rico, Carmen Méndez García, Joanne Neff van Aertselaer y Ana Laura Rodríguez Redondo. Madrid: Fundamentos. 2010. 201-212. 
— «Eighteenth-Century Irish Authors as New and Elegant Amusements for the Ladies of Great Britain». Glocal Ireland: Current Perspectives on Literature and the Visual Arts. Eds. Marisol Morales Ladrón y Juan Elices. Newcastle upon Tyne: Cambridge Scholars Publishing, 2011. 40-50.

Moro Martín, Alfredo «Fielding, Neugebauer, Musäus y Wieland: la literatura inglesa y su papel en el nacimiento de la tradición novelística alemana». A View from the South: Contemporary English and American Studies. Eds. José R. Ibáñez Ibáñez y José Francisco Fernández Sánchez Almería: Editorial Universidad de Almería, 2011. 61-67.

Shenzad Zaidi, Ali. «The Dark Interiors of Arthur Mervyn». The Grove: Working Papers on English Studies 18 (2011): 13-30.

\section{Siglo XIX}

Balakrishnan, Manjula. «Humour and Fear: A Study of the Humoristic Resources in Wilde's The Canterville Ghost». Epos: Revista de Filología 27 (2011): 203-212.

Ballesteros González, Antonio, ed. y trad. Poesía romántica inglesa. Antología bilingüe. Madrid: Publicaciones de la Asociación de Directores de Escena de España, 2011.

Bautista-Naranjo, Esther. «Dorian Gray's Fall from Grace, the Price to Pay for Immortality». Acculturating Age. Approaches to Cultural Gerontology. Ed. Brian J. Worsfold. Lleida: University of Lleida, 2011. 189-206.

Berkencotter, Carol. «A Patient's Tale of Incarceration in a Victorian Lunatic Asylum». IJES. International Journal of English Studies 11.1 (2011): 1-14.

Chaparro Domínguez, M. ${ }^{a}$ Carmen. «La huella de la sociedad victoriana en The Island of Doctor Moreau (1896) y The Island of Lost Souls (1932)». Espéculo. Revista de Estudios Literarios 47 (2011). Revista electrónica.

Dedebas, Eda. «Christina Rossetti's Speaking Likenesses: Different Forms of Travel in Victorian Children's Literature». Extravío. Revista electrónica de literatura comparada 6 (2011): 53-68.

Fernández Rodríguez, M. ${ }^{a}$ Carmen. «Frances Burney and Female Friendships: Some Notes on Cecilia (1783) y The Wanderer (1814)». Journal of English Studies 9 (2011): 109-124.

— «Frances Burney and Sarah Harriet Burney: a Comparison between The Wanderer (1814) and The Renunciation (1839)». ES: Revista de Filología Inglesa 32 (2011): 91-112.

- "'In true old maid character': El universo femenino en Country Neighbours or the Secret (1820) de Sarah Harriet Burney». Oceánide 3 (2011). Revista electrónica.

— «Romanticising the Robinsonade: Sarah Harriett Burney's The Shipwreck (1820)». Babel afial: Aspectos de filología inglesa y alemana 20 (2011): 21-39.

Flores Moreno, Cristina. «William Blake's Legacy in Miguel de Unamuno's Mature Poetry and Poetics». Estudios Ingleses de la Universidad Complutense 19 (2011): 89-104.

Font Paz, Carmen. «Women Periodicals in the New Woman Print Culture of Fin-de Siècle Britain». Odisea: Revista de Estudios Ingleses 12 (2011): 125-136.

González Cruz, M. ${ }^{a}$ Isabel. «Hispanismos y canarismos en los textos de dos viajeras inglesas decimonónicas». Revista de filología de la Universidad de La Laguna 29 (2011): 81-100.

Hesles Sánchez, Germán José. «Elois y Morlocks. Darwin y la máquina del tiempo: Wells y Mendizábal, visiones contrapuestas de una evolución imaginada». Espéculo. Revista de Estudios Literarios 47 (2011). Revista electrónica.

Krauel Heredia, Blanca. «Viajando por Andalucía: el testimonio de algunas escritoras victorianas». Revista de filología de la Universidad de La Laguna 29 (2011): 141-162.

LÁzaro, Alberto. «Reading Oscar Wilde in Post-War Spain: The Picture of Dorian Gray under the Microscope». Dreaming the Future: New Horizons / Old Barriers in 21st-Century Ireland. 
Eds. María Losada Friend, José María Tejedor Cabrera, José Manuel Estévez-Saá y Werner Huber. Trier, Alemania: WVT Wissenschaftlicher Verlag Trier, 2011. 43-50.

Martín EzPeleta, Antonio. «El viaje por España de George Ticknor y sus diarios (1818)». 1616. Anuario de la Sociedad Española de Literatura General y Comparada 1 (2011): 25-47.

Miquel Baldellou, Marta. «Horrorizando a Jane Austen: del matrimonio, la muerte y la mujer de clase media». Oceánide 3 (2011). Revista electrónica.

- «From the Young Student to the Old Caxtonian: Edward Bulwer-Lytton's Lifetime Reflections on Victorian Ageing». Acculturating Age. Approaches to Cultural Gerontology. Ed. Brian J. Worsfold. Lleida: University of Lleida, 2011. 229-247.

- «Transatlantic Doubles: Intertextual Ageing in the Early Fiction of Edgar Allan Poe and Edward Bulwer-Lytton». Odisea: Revista de Estudios Ingleses 12 (2011): 149-164.

Miralles Pérez, Antonio José. «La ficción medieval de Arthur Conan Doyle». Odisea: Revista de Estudios Ingleses 12 (2011): 351-360.

Moreno Carrascal, José M. ${ }^{\mathrm{a}}$. «'Self” y sociedad en la secuencia poética Transformations de D. H. Lawrence». Epos: Revista de Filología 27 (2011): 213-222.

Owen, David. "'Remarkably Unpolitical': Really? Contextualising a Political Reading of Jane Austen's Lady Susan». A View from the South: Contemporary English and American Studies. Eds. José R. Ibáñez Ibáñez y José Francisco Fernández Sánchez Almería: Editorial Universidad de Almería, 2011. 272-279.

Rodríguez Ravelo, Cristina. «Oscar Wilde's Humorous Manipulations of Discourse with 'Elaborate Politeness' in The Importance of Being Earnest». Babel afial: Aspectos de filología inglesa y alemana 20 (2011): 71-86.

Romero IlLÁn, Sagrario. «Louisa May Alcott y Charlotte Brontë: la lucha por la emancipación y la ruptura con las convenciones sociales». A View from the South: Contemporary English and American Studies. Eds. José R. Ibáñez Ibáñez y José Francisco Fernández Sánchez Almería: Editorial Universidad de Almería, 2011. 86-92.

SAÉz, Rodrigo. «Dicen que dicen que andan diciendo...: a propósito de la perturbación del lenguaje en Frankenstein, de Mary Shelley, y ¡Pobres criaturas!, de Alasdair Gray». Espéculo. Revista de Estudios Literarios 46 (2010-11). Revista electrónica.

\section{Siglo XX y ContemporáneA}

Aguilera Linde, Mauricio D. «Ernest Hemingway (1899-1961)». Writers of the Spanish Civil War: The Testimony of Their Auto/Biographies. Ed. Celia Wallhead Berna: Peter Lang, 2011. 137-186.

Alonso Giráldez, José Miguel. «Ulysses as a Musical Composition: Structure, Key and Cadence». JoyceSbilya. Miscelánea de Estudios Joyceanos. Coord. José María Tejedor Cabrera et al. Sevilla: Universidad de Sevilla, 2011. 175-184.

Altuna García de Salazar, Asier. «Glocalising, Globalising: Emer Martin's Fiction». Glocal Ireland: Current Perspectives on Literature and the Visual Arts. Eds. Marisol Morales Ladrón y Juan F. Elices Agudo. Newcastle: Cambridge Scholars Publishing, 2011. 168-179.

Álvarez Pérez, Iciar. «The Linden Tree in 'The dead' by James Joyce». Odisea: Revista de Estudios Ingleses 12 (2011): 29-38.

Aragay, Mireia. «A Mirror of Our Own Anxiety: Civilization, Violence and Ethics in Martin Crimp's Cruel and Tender». Atlantis. Journal of the Spanish Association of Anglo-American Studies 33.2 (2011): 75-87.

Becketт, Samuel. Sueño con mujeres que ni fu ni fa. Trad. José Francisco Fernández y Miguel Martínez-Lage. Barcelona: Tusquets, 2011. 
Bret Franco, Carolina. «¿Por qué es 'The Thing in The Forest' de A. S. Byatt un relato posmodernista?». Espéculo. Revista de Estudios Literarios 46 (2010-11). Revista electrónica.

CARretero González, Margarita. «Robert Graves (1895-1985)». Writers of the Spanish Civil War: The Testimony of Their Auto/Biographies. Ed. Celia Wallhead Berna: Peter Lang, 2011. 65-136.

Claros Morales, M. ${ }^{a}$ José. «Seamus Heaney's 'District and Circle': From the Omphalos to the Universal». Glocal Ireland: Current Perspectives on Literature and the Visual Arts. Eds. Marisol Morales Ladrón y Juan F. Elices Agudo. Newcastle upon Tyne: Cambridge Scholars Publishing, 2011. 118-126.

Cuder Domínguez, Pilar. «Black Bodies in History: Bernardine Evaristo's Fiction». Cultural Migrations and Gendered Subjects: Colonial and Postcolonial Representations of the Female Body. Eds. Silvia Castro Borrego y María Isabel Romero Ruiz. Newcastle upon Tyne: Cambridge Scholars Publishing, 2011. 55-74.

Del Río Molina, Beningno. «Geography of Desire and Guilt: Joyce's 'Circe' in the tradition of The Temptation of Saint Anthony». Dreaming the Future: New Horizons / Old Barriers in 21stCentury Ireland. Eds. María Losada Friend, José María Tejedor Cabrera, José Manuel EstévezSaá y Werner Huber. Trier, Alemania: WVT Wissenschaftlicher Verlag Trier, 2011. 25-32.

— «Liturgia de los velos: dialéctica del ver y no ver en las artes visuales y en Ulysses». JoyceSbilya. Miscelánea de Estudios Joyceanos. Coord. José María Tejedor Cabrera et al. Sevilla: Universidad de Sevilla, 2011. 81-100.

Delattre, Elisabeth. «Michael Longley's Poetry of the Elements in Snow Water». Estudios Irlandeses 6 (2011): 1-7.

Díaz López, Juan Antonio. «Gerald Brenan (1894-1987)». Writers of the Spanish Civil War: The Testimony of Their Auto/Biographies. Ed. Celia Wallhead Berna: Peter Lang, 2011. 19-64.

Díez García, M. José. «Arrabalian Echoes in Martin McDonagh's The Pillowman». A View from the South: Contemporary English and American Studies. Eds. José R. Ibáñez Ibáñez y José Francisco Fernández Sánchez Almería: Editorial Universidad de Almería, 2011. 265-271.

Eliot, T. S. La aventura sin fin. Ensayos. Ed. Andreu Jaume, trad. Juan Antonio Montiel. Barcelona: Lumen, 2011.

Fayez Khasawneh, Hana. «The Irish Modernist Literary Writing: A Dialogic Space». Oceánide 3 (2011). Revista electrónica.

Fernández Quesada, Nuria. «Under the Aegis of the Lord Chamberlain and the Franco Regime: the Bowdlerisation of Waiting for Godot and Endgame». Censorship across Borders: The Reception of English Literature in Twentieth-Century Europe. Eds. Catherine O'Leary y Alberto Lázaro. Newcastle upon Tyne: Cambridge Scholars Publishing, 2011. 193-210.

Fernández SÁnchez, José Francisco. «¿Acto de rebeldía o prueba de admiración? Beckett parodiando a Joyce». JoyceSbilya. Miscelánea de Estudios Joyceanos. Coord. José María Tejedor Cabrera et al. Sevilla: Universidad de Sevilla, 2011. 115-124.

- ed. Margaret Drabble: A Day in the Life of a Smiling Woman. The Collected Stories. Londres: Penguin Classics, 2011.

- «Samuel Beckett and Aidan Higgins: No Intrusion Involved». Glocal Ireland: Current Perspectives on Literature and the Visual Arts. Eds. Marisol Morales Ladrón y Juan F. Elices Agudo. Newcastle upon Tyne: Cambridge Scholars Publishing, 2011. 127-138.

— «Spanish Beckett». Dreaming the Future: New Horizons / Old Barriers in 21st-Century Ireland. Eds. María Losada Friend, José María Tejedor Cabrera, José Manuel Estévez-Saá y Werner Huber. Trier, Alemania: WVT Wissenschaftlicher Verlag Trier, 2011. 63-74.

Fernández Vicente, Olga. «Crisis de fin de siglo en Joyce y Baroja». JoyceSbilya. Miscelánea de Estudios Joyceanos. Coord. José María Tejedor Cabrera et al. Sevilla: Universidad de Sevilla, 2011. 125-138. 
Gámez Fernández, Cristina María. «The Landscape as Metaphor in Eavan Boland's Against Love Poetry». The Grove: Working Papers on English Studies 18 (2011): 87-104.

García LEÓN, Rafel I. «Demostración por álgebra de que el nieto de Hamlet es el abuelo de Shakespeare (U 1.154-5 y 2.151-2)». JoyceSbilya. Miscelánea de Estudios Joyceanos. Coord. José María Tejedor Cabrera et al. Sevilla: Universidad de Sevilla, 2011. 33-42.

García Tortosa, Francisco. «Caminos a Joyce». JoyceSbilya. Miscelánea de Estudios Joyceanos. Coord. José María Tejedor Cabrera et al. Sevilla: Universidad de Sevilla, 2011. 21-32.

Gaviña Costero, María. Érase una vez Ballybeg. La obra dramática de Brian Friel y su repercusión en España. Saarbrücken: Lambert Academic Publishing, 2011.

Gómez Seonne, Almudena María y Fernández Santomé, Cecilia. «Reescribiendo el vacío: colonialismo y feminismo frente a la conquista de la tierra virgen. El caso de Joseph Conrad y Claire Lejeune». Odisea: Revista de Estudios Ingleses 12 (2011): 307-318.

GonzÁLEZ Alarcón. «George Moore: la pasión francesa». Odisea: Revista de Estudios Ingleses 12 (2011): 319-330.

González Arias, Luz Mar. «'Dealing with Themes as They Arrive’: A Conversation with Mary O'Donnell». Glocal Ireland: Current Perspectives on Literature and the Visual Arts. Eds. Marisol Morales Ladrón y Juan F. Elices Agudo. Newcastle upon Tyne: Cambridge Scholars Publishing, 2011. 252-267.

Hernando Real, Noelia. Self and Space in the Theater of Susan Glaspell. Jefferson, NC: McFarland, 2011.

Keatinge, Benjamin. «Responses to the Holocaust in Modern Irish Poetry». Estudios Irlandeses 6 (2011): 21-38.

León TÁvora, Ana. «The Aryan Joyce: Use of the Swastika in Finnegans Wake». JoyceSbilya. Miscelánea de Estudios Joyceanos. Coord. José María Tejedor Cabrera et al. Sevilla: Universidad de Sevilla, 2011. 65-80.

LitT, Toby. "The Curse of the Cursor». A View from the South: Contemporary English and American Studies. Eds. José R. Ibáñez Ibáñez y José Francisco Fernández Sánchez Almería: Editorial Universidad de Almería, 2011. 45-46.

Llorens-Cubedo, Dídac. «The Days of Darkness in the Poetry of T. S. Eliot and Salvador Espriu». Acculturating Age. Approaches to Cultural Gerontology. Ed. Brian J. Worsfold. Lleida: University of Lleida, 2011. 207-227.

LosAdA FriEnd, María. «Desmantelando el cuerpo femenino: la emoción objetiva de Mary Hooligan de Edna O’Brien o Molly Bloom de James Joyce». JoyceSbilya. Miscelánea de Estudios Joyceanos. Coord. José María Tejedor Cabrera et al. Sevilla: Universidad de Sevilla, 2011. 139-152.

- Tejedor Cabrera, José María, Estévez-SaÁ, José Manuel y Huber, Werner, eds. Dreaming the Future: New Horizons / Old Barriers in 21st-Century Ireland. Trier, Alemania: WVT Wissenschaftlicher Verlag Trier, 2011.

Marín RuIz, Ricardo. Tres visiones de España durante la guerra civil. 'L'espoir', 'Homage to Catalonia' y 'For Whom the Bell Tolls'. Murcia: Nausicaa, 2011.

MartíneZ-Alfaro, María Jesús. «Where Madness Lies: Holocaust Representation and the Ethics of Form in Martin Amis' Time's Arrow». Ethics and Trauma in Contemporary British Fiction. Eds. Susana Onega y Jean-Michel Ganeau. Amsterdam / Nueva York: Rodopi, 2011. 127-154.

Martínez TorRes, Francisco y Robert Ian MAcCANDLESS. «Simbología masónica en Ulysses a través de La flauta mágica de Mozart». JoyceSbilya. Miscelánea de Estudios Joyceanos. Coord. José María Tejedor Cabrera et al. Sevilla: Universidad de Sevilla, 2011. 53-64.

Mccorristine, Shane. «William Fletcher Barrett, Spiritualism, and Psychical Research in Edwardian Dublin». Estudios Irlandeses 6 (2011): 39-53.

Monterrey, Tomás. «Framed Images as Counterpoints in James Joyce's 'The Dead'». Atlantis. Journal of the Spanish Association of Anglo-American Studies 33.2 (2011): 61-74. 
Morales Ladrón, Marisol. "'My Loyalties would Always be with the Local': A Conversation with Deirdre Madden». Glocal Ireland: Current Perspectives on Literature and the Visual Arts. Eds. Marisol Morales Ladrón y Juan F. Elices Agudo. Newcastle upon Tyne: Cambridge Scholars Publishing, 2011. 244-251.

Morató Agrafojo, Yolanda. «Wyndham Lewis and the Different Forms of Censorship». ES: Revista de Filología Inglesa 32 (2011): 225-240.

Navarro Romero, Betsabé. «Coming to Terms with 21st Century Bristish Politics: An interview with Toby Litt». Journal of English Studies 9 (2011): 265-274.

- «Playing with Collective Memories: Julian Barnes' England, England and New Labour's Rebranding of Britain». ES: Revista de Filología Inglesa 32 (2011): 241-262.

Nayar, Pramod K. "'Novel Globalism', the Transnational Exotic and Spectral Cosmopolitanish: David Mitchell's Fiction». The Grove: Working Papers on English Studies 18 (2011): 69-86.

Oliva Cruz, Juan Ignacio. «Gendered Re-readings of the Irish Canon in Jamie O'Neill's At Swim, Two Boys». Glocal Ireland: Current Perspectives on Literature and the Visual Arts. Eds. Marisol Morales Ladrón y Juan F. Elices Agudo. Newcastle upon Tyne: Cambridge Scholars Publishing, 2011. 87-99.

— «Rewriting Ireland through Fractured Male Selves in the Works of Jamie O'Neill». Dreaming the Future: New Horizons / Old Barriers in 21 st-Century Ireland. Eds. María Losada Friend, José María Tejedor Cabrera, José Manuel Estévez-Saá y Werner Huber. Trier, Alemania: WVT Wissenschaftlicher Verlag Trier, 2011. 51-62.

Olivares Leyva, Mónica. «The Controversy Regarding Graham Greene in Spain». Censorship across Borders: The Reception of English Literature in Twentieth-Century Europe. Eds. Catherine O Leary y Alberto Lázaro. Newcastle upon Tyne: Cambridge Scholars Publishing, 2011. 161-170.

OnEga, Susana. «The Trauma Paradigm and the Ethics of Affect in Jaenette Winterson's The Stone Gods». Ethics and Trauma in Contemporary British Fiction. Eds. Susana Onega y JeanMichel Ganeau. Amsterdam / Nueva York: Rodopi, 2011. 265-298.

- y Ganeau, Jean-Michel, eds. Ethics and Trauma in Contemporary British Fiction. Amsterdam / Nueva York: Rodopi, 2011.

Oró-Piqueras, Maricel. «Wrinkles and Selves: Time and Memory through the Ageing Body in Penelope Lively's Spiderweb and Doris Lessing's Love, Again». Acculturating Age. Approaches to Cultural Gerontology. Ed. Brian J. Worsfold. Lleida: University of Lleida, 2011. 153-166.

Ortega Sáez, Marta. «The Reception of Rosamond Lehmann in Franco's Spain». Censorship across Borders: The Reception of English Literature in Twentieth-Century Europe. Eds. Catherine O Leary y Alberto Lázaro. Newcastle upon Tyne: Cambridge Scholars Publishing, 2011. 171-192.

Patea, Viorica. «Eliot, Dante and the Poetics of a 'Unified Sensibility'». T. S. Eliot, Dante and the Idea of Europe. Ed. Paul Douglass. Newcastle upon Tyne: Cambridge Scholars Publishing, 2011. 15-27.

Pellicer-Ortín, Silvia. «The Ethical Clock of Trauma in Eva Figes' White Journey». Ethics and Trauma in Contemporary British Fiction. Eds. Susana Onega y Jean-Michel Ganeau. Amsterdam / Nueva York: Rodopi, 2011. 37-60.

— «Testimony and the Representation of Trauma in Eva Figes' Journey to Nowhere». Atlantis. Journal of the Spanish Association of Anglo-American Studies 33.1 (2011): 69-84.

PÉrez VIDEs, Auxiliadora. «'The Theatre of the Family': An Irish Approach to Gender Awareness in Catherine Dunne's Fiction». Odisea: Revista de Estudios Ingleses 12 (2011): 183-194.

Pettersson, Lin. «Freakery and Spectacle of the Divergent Body in Hilary Mantel's The Giant, O'Brien». A View from the South: Contemporary English and American Studies. Eds. José 
R. Ibáñez Ibáñez y José Francisco Fernández Sánchez Almería: Editorial Universidad de Almería, 2011. 280-286.

RaWASHDEH, Mohammed. «Against the Grain: Ireland, Myth, and Globalization in W. B. Yeats's Drama». The Grove: Working Papers on English Studies 18 (2011): 31-52.

Rey TorriJos, Esther. «Everything is Moving: Speed and Sense of Place in Elizabeth Bowen's Novels». Glocal Ireland: Current Perspectives on Literature and the Visual Arts. Eds. Marisol Morales Ladrón y Juan F. Elices Agudo. Newcastle: Cambridge Scholars Publishing, 2011. 62-78.

Roberts Shumaker, Jeanette. «Sado-Masochism in Clare Boylan's Home Rule and Holy Pictures». Estudios Irlandeses 6 (2011): 91-102.

Rodríguez Fernández, M. ${ }^{\text {a }}$ Carmen. «Rostros con historias: un viaje al mundo de 'Los Muertos' según J. Joyce y J. Huston». JoyceSbilya. Miscelánea de Estudios Joyceanos. Coord. José María Tejedor Cabrera et al. Sevilla: Universidad de Sevilla, 2011. 153-166.

Rodríguez Salas, Gerardo y Andrés-Cuevas, Isabel María. The Aesthetic Construction of the Female Grotesque in Katherine Mansfield and Virginia Woolf: A Study of the Interplay of Life and Literature. Lewiston, Nueva York: The Edwin Mellen Press, 2011.

Royo Grasa, Agustín. «Towards the Fifth Province: Brian Friel's Translations of Stereotypes». Odisea: Revista de Estudios Ingleses 12 (2011): 205-216.

Ruiz Martínez, M. ${ }^{a}$ Mar. "Aproximaciones a una 'tradición menor': el relato corto contemporáneo en Gran Bretaña». A View from the South: Contemporary English and American Studies. Eds. José R. Ibáñez Ibáñez y José Francisco Fernández Sánchez Almería: Editorial Universidad de Almería, 2011. 368-374.

Ryan, Mary. «Then and Now: Memories of a Patriarchal Ireland in the Work of Marian Keyes». $452^{\circ}$ F: Revista de Teoría de la Literatura y Literatura Comparada 4 (2011): 110-130.

SAcido Romero, Jorge. «Failed Exorcism: Kurtz's Spectral Status and Its Ideological Function in Conrad's Heart of Darkness». Atlantis. Journal of the Spanish Association of Anglo-American Studies 33.2 (2011): 43-60.

- y Lojo Rodríguez, Laura. «Through the Eye of a Postmodernist Child: Ian McEwan's 'Homemade'». Miscelánea: A Journal of English and American Studies 44 (2011): 107-120.

SAÉz, Rodrigo. «Dicen que dicen que andan diciendo...: a propósito de la perturbación del lenguaje en Frankenstein, de Mary Shelley, y iPobres criaturas!, de Alasdair Gray». Espéculo. Revista de Estudios Literarios 46 (2010-11). Revista electrónica.

SÁnchez Cuervo, Margarita. «The Essay as Story and the Story in the Essay: Narrative as Argument in Virginia Woolf's Essays». A View from the South: Contemporary English and American Studies. Eds. José R. Ibáñez Ibáñez y José Francisco Fernández Sánchez Almería: Editorial Universidad de Almería, 2011. 101-107.

SÁncheZ-García, Celina. «Metafiction against and with Nature: Ali Smith's The Whole Story and Other Stories». A View from the South: Contemporary English and American Studies. Eds. José R. Ibáñez Ibáñez y José Francisco Fernández Sánchez Almería: Editorial Universidad de Almería, 2011. 108-114.

SÁnchez Pardo, Esther. «Poetry and Cultural Memory: the Work of Mourning and Beyond». A View from the South: Contemporary English and American Studies. Eds. José R. Ibáñez Ibáñez y José Francisco Fernández Sánchez Almería: Editorial Universidad de Almería, 2011. 115-120.

- «Why Memorialize? Stephen Spender's Aesthetics of Remembrance in Vienna». Revista canaria de estudios ingleses 63 (2011): 39-52.

San José Rico, Patricia y Mezquita Fernández, María Antonia. «Escaping Trauma through a Dreamworld: Fantasy and the Evasion of Pain in Jane Yolen's Briar Rose and John Boyne's The Boy in the Striped Pyjamas». ES: Revista de Filología Inglesa 32 (2011): 301-316. 
Sanz Gallego, Guillermo. «Ulysses as a Musical Composition: Structure, Key and Cadence». JoyceSbilya. Miscelánea de Estudios Joyceanos. Coord. José María Tejedor Cabrera et al. Sevilla: Universidad de Sevilla, 2011. 167-174.

Simmons, Jeffrey. «Three Views of the Modernist J.». JoyceSbilya. Miscelánea de Estudios Joyceanos. Coord. José María Tejedor Cabrera et al. Sevilla: Universidad de Sevilla, 2011. 43-52.

Sмiтh, Stewart. «The Poet's Blueprint: The Pastoral and the Avant-Garde in Ian Hamilton Finlay's Poor.Old.Tired.Horse». Revista canaria de estudios ingleses 62 (2011): 55-70.

Tejedor Cabrera, José María et al, coord. JoyceSbilya. Miscelánea de Estudios Joyceanos. Sevilla: Universidad de Sevilla, 2011.

TINnELL, Roger. «A New Look at John Stanley Richardson in Spain». Revista canaria de estudios ingleses 63 (2011): 9-20.

Van Bleisswisk, Corneeltje. «African Pride vs. English Prejudice: The Yearnings of Metropolitan Women in Maggie Gee's My Cleaner». A View from the South: Contemporary English and American Studies. Eds. José R. Ibáñez Ibáñez y José Francisco Fernández Sánchez Almería: Editorial Universidad de Almería, 2011. 307-313.

Villar Argáiz, Pilar. "'A Global Regionalist': Paula Meehan's Transnational Poetics of Globalisation». Glocal Ireland: Current Perspectives on Literature and the Visual Arts. Eds. Marisol Morales Ladrón y Juan F. Elices Agudo. Newcastle: Cambridge Scholars Publishing, 2011. 100-117.

Wallhead, Celia. «Laurie Lee (1914-1997)». Writers of the Spanish Civil War: The Testimony of Their Auto/Biographies. Ed. Celia Wallhead Berna: Peter Lang, 2011. 281-318.

- ed. Writers of the Spanish Civil War: The Testimony of Their Auto/Biographies. Berna: Peter Lang, 2011.

Waugh, Evelyn. Rendición incondicional. Ed. Carlos Villar Flor, trad. Carlos Villar Flor y Gabriel Insausti. Madrid: Cátedra, 2011.

Yebra, José María. «'A Terrible Beauty': Ethics, Aesthetics and the Trauma of Gayness in Alan Hollinghurst's The Line of Beauty». Ethics and Trauma in Contemporary British Fiction. Eds. Susana Onega y Jean-Michel Ganeau. Amsterdam / Nueva York: Rodopi, 2011. 175-208.

— «The 'Moving' Lines of Neo-Baroque in Will Self's Dorian: An Imitation». Atlantis. Journal of the Spanish Association of Anglo-American Studies 33.1 (2011): 17-31.

Zurbano García, Daniel. «The Reader's Response to 'A Mother'». JoyceSbilya. Miscelánea de Estudios Joyceanos. Coord. José María Tejedor Cabrera et al. Sevilla: Universidad de Sevilla, 2011. 101-114. 


\section{B. LITERATURA NORTEAMERICANA}

DídAC Llorens Cubedo

UNED. Madrid

dllorens@ flog.uned.es

Alonso Alonso, María. «Marvellous Syncretism in Katheleen Alcalá's Trilogy about the Sonoran Desert». ES: Revista de Filología Inglesa 32 (2011): 7-25.

- «Textual Representation of Chicana Identity in Sandra Cisneros's Caramelo, or, Puro Cuento». Odisea: Revista de Estudios Ingleses 12 (2011): 15-28.

Alonso Recarte, Claudia. «Marketing Strategies, Consumerism and the Exercise of Democracy in W. H. H. Murray's Adventures in the Wilderness; or, Camp-Life in the Adirondacks». Atlantis. Journal of the Spanish Association of Anglo-American Studies 33.1 (2011): 53-68.

Arce Álvarez, M. ${ }^{a}$ Laura. «Conspiracy and Betrayal in the Shade of McCarthy's America: Philip Roth's I Married a Communist». ES: Revista de Filología Inglesa 32 (2011): 27-42.

- «Inside the Locked Room: the Concept of Space and Author in Paul Auster's Travels in the Scrptorium». A View from the South: Contemporary English and American Studies. Eds. José R. Ibáñez Ibáñez y José Francisco Fernández Sánchez Almería: Editorial Universidad de Almería, 2011. 421-426.

Baelo Allué, Sonia. Bret Easton Ellis's Controversial Fiction: Writing Between High and Low Culture. Londres y Nueva York: Continuum, 2011.

Beltrán, José, Garrido, Manuel, Sevilla, Sergio, eds. Santayana: un pensador universal. Biblioteca Javier Coy d'Estudis Nord-Americans. Valencia: Universitat de València, 2011.

Bosch, Marta. «Post-9/11 Representations of Arab Masculinities by Arab American Women Writers: Criticism or Praise?». Men in Color: Racialized Masculinities in U.S. Literature and Cinema. Ed. Josep M. Armengol. Newscatle upon Tyne: Cambridge Scholars Publishing, 2011. 33-56.

Bravo Castillo, Juan. «Poe visto por Baudelaire». Los legados de Poe. Ed. Margarita Rigal. Madrid: Síntesis, 2011. 175-186.

BRíGIDO-Corachán, Anna M. «Native Journeys of Self-Figuration: N. Scott Momaday's The Way to Rainy Mountain and Gloria Anzaldúa's Borderlands / La Frontera». Selves in Dialogue: A Transethnic Approach to American Life Writing. Ed. Begoña Simal. Amsterdam / New York: Rodopi, 2011. 109-132.

Bushrui, Suheil. «The Enduring Legacy of Kahlil Gibran». Odisea: Revista de Estudios Ingleses 12 (2011): 7-15.

Calvo-Pascual, Mónica. Chaos and Madness: The Politics of Fiction in Stephen Marlowe's Historical Narratives. Amsterdam / Nueva York: Rodopi, 2011.

Cantizano Márquez, Blasina. «De Mujeres y Pájaros: Birds of America de Lorrie Moore». A View from the South: Contemporary English and American Studies. Eds. José R. Ibáñez Ibáñez y José Francisco Fernández Sánchez Almería: Editorial Universidad de Almería, 2011. 348-354.

Castillo Martín, Francisco Javier. 'Poe y la ciencia ficción’. Los legados de Poe. Ed. Margarita Rigal. Madrid: Síntesis, 2011. 62-80. 
Castro-Borrego, Silvia Pilar. «Introduction: From Fragmentation to Wholeness, an Exploration». The Search for Wholeness and Diaspora Literacy in Contemporary African American Literature. Ed. Silvia Pilar Castro-Borrego. Newcastle upon Tyne: Cambridge Scholars Publishing, 2011. 1-18.

— «Migrations of the Self: The Search for Identity and Wholeness in Bebe Moore Campbell's Novel What You Owe Me». Cultural Migrations and Gendered Subjects: Colonial and Postcolonial Representations of the Female Body. Eds. Silvia Castro-Borrego y María Isabel Romero Ruiz. Newcastle upon Tyne: Cambridge Scholars Publishing, 2011. 99-124.

— «Praisesong for the Widow as Narrative of Restoration: Reading Black Women's Search for Spiritual Wholeness». The Search for Wholeness and Diaspora Literacy in Contemporary African American Literature. Ed. Silvia Pilar Castro-Borrego. Newcastle upon Tyne: Cambridge Scholars Publishing, 2011. 189-212.

- , ed. The Search for Wholeness and Diaspora Literacy in Contemporary African American Literature. Newcastle upon Tyne: Cambridge Scholars Publishing, 2011.

Claudio Moreno, Esther. «Blurring Boundaries between Fiction and Reality: Escapsim and Hyperreality in Coover's The Universal Baseball Association, Inc., J. Henru Waugh, Propietor». A View from the South: Contemporary English and American Studies. Eds. José R. Ibáñez Ibáñez y José Francisco Fernández Sánchez Almería: Editorial Universidad de Almería, 2011. 258-264.

- «Evasión e hiperrealidad en The Universal Baseball Association, Inc., J. Henry Waugh, Proprietor». Estudios Ingleses de la Universidad Complutense 19 (2011): 105-129.

CoRPI, Lucha. Loa a un ángel de piel morena. Trad. Nuria Brufau. Colección «Camino Real». Alcalá de Henares: Instituto Franklin - UAH, 2011.

Crone, Moira. «A View from the South of the South». A View from the South: Contemporary English and American Studies. Eds. José R. Ibáñez Ibáñez y José Francisco Fernández Sánchez Almería: Editorial Universidad de Almería, 2011. 1-8.

Cuenca, Mercè. «'You do not do:' Deconstructing White Masculinity in Cold War American Literature (1945-1965)». Men in Color: Racialized Masculinities in U.S. Literature and Cinema. Ed. Josep M. Armengol. Newscatle upon Tyne: Cambridge Scholars Publishing, 2011. 121-142.

DeBritto, Abel. «'Sunlight Coming Down’: The Early Chapbooks of Charles Bukowski». Revista canaria de estudios ingleses 62 (2011): 43-54.

De Souza Frota, Adolfo José. «Puritanismo e alegoria: o conflito entre o bem e o mal em 'O jovem Goodman Brown'». Espéculo. Revista de Estudios Literarios 47 (2011). Revista electrónica.

Dickinson, Emily. Oblicuidad de luz (95 poemas). Ed. Rolando Costa Picazo. Biblioteca Javier Coy d'Estudis Nord-Americans. Valencia: Universitat de València, 2011.

Domínguez-RuÉ, Emma. «Good Old Men in the New South: Portraits of Elderly Male Characters in the Fiction of Ellen Glasgow». Acculturating Age. Approaches to Cultural Gerontology. Ed. Brian J. Worsfold. Lleida: University of Lleida, 2011. 263-279.

Durán Almarza, Elina M. ${ }^{\mathrm{a}}$ «Chewing English and Spitting Spanish: Josefina Báez Homing Dominican New York» Camino real. Cuaderno de Hispanidades Norteamericanas 4 (2011): 73-94.

Farré Vidal, Carme. «Dissecting Patricia Cornwell's Dr. Kay Scarpetta in the Forensic Laboratory». Revista canaria de estudios ingleses 63 (2011): 65-76.

Fernández-Morales, Marta. «The New Breast Cancer (Im)patient: Female Revolt against Biomedical Violence in US Drama». Performing Gender Violence: Plays by Contemporary American Women Writers. Eds. Barbara Ozieblo y Noelia Hernando-Real. Nueva York: Palgrave McMillan, 2011. 97-112.

— , Pineda-Hernández, Inmaculada, López-Rodríguez, Miriam y Ozieblo, Barbara. «Violence Against Women: Forms and Responses». Performing Gender Violence: Plays by 
Contemporary American Women Writers. Eds. Barbara Ozieblo y Noelia Hernando-Real. Nueva York: Palgrave McMillan, 2011. 15-26.

Ferrús, Beatriz. Mujer y literatura de viajes en el siglo XIX: entre España y las Américas. Biblioteca Javier Coy d'Estudis Nord-Americans. Valencia: Universitat de València, 2011.

FrA, Patricia, ed. Edith Wharton. Back to Compostela. Regreso a Compostela. Santiago de Compostela: Universidade de Santiago, 2011.

Galdón Rodríguez, Ángel. 'Anexo I: Mapa biográfico'. Los legados de Poe. Ed. Margarita Rigal. Madrid: Síntesis, 2011. 221-226.

Gallego Dúran, M. ${ }^{a}$ del Mar. «El racismo científico del siglo XVIII y las estrategias de auto-representación: la narrativa interesante de Olaudah Equiano». Estudios Ingleses de la Universidad Complutense 19 (2011): 71-87.

García Avello, Macarena. «'I’ve always known...'. La mística de la feminidad en Revolutionary Road de Richard Yates». Odisea: Revista de Estudios Ingleses 12 (2011): 289-306.

Garipova, Nailya. «La heroína principal de Nabokov-Sirin: la literatura rusa en The Gift». The Grove: Working Papers on English Studies 18 (2011): 143-162.

— «The Original of Laura: a Great Novel that Never Was». ES: Revista de Filología Inglesa 32 (2011): 113-124.

Gimeno Pahissa, Laura. «From Slave to Historian: the Case of James Lindsay Smith's Postbellum Autobiography». ES: Revista de Filología Inglesa 32 (2011): 125-146.

Gómez Galisteo, M. ${ }^{a}$ Carmen. "'For the Benefit of the Afflicted?': American Captivity Narratives from Mary Rowlandson to Jessica Lynch». Babel afial: Aspectos de filología inglesa y alemana 20 (2011): 41-56.

- «What Men and Women Do When They Talk about Love: A Sociolinguistic Analysis of 'What We Talk About When We Talk About Love' by Raymond Carver». Journal of English Studies 9 (2011): 125-142.

González LóPez, Jesús A. «Western Images in Paul Auster's Work: From Moon Palace to Later Fiction». Beyond the Myth: New Perspectives on Western Texts. Eds. David Rio, Amaia Ibarraran y Martin Simonson. Londres: Portal, 2011. 63-82.

- y Ciocia, Stefania, eds. The Invention of Illusions: International Perspectives on Paul Auster. Newcastle upon Tyne: Cambridge Scholars Publishing, 2011.

González Mínguez, Teresa. «E. E. Cummings and the Modern Man: On How the Concept of Masculinity Evolves in His Poetry». Babel afial: Aspectos de filología inglesa y alemana 20 (2011): 57-70.

— «Medievalism in E. E. Cummings' Works: Dante, Chaucer and the Troubadors Among the Modern.» Focus on Old and Middle English Studies. Eds. Ana Laura Rodríguez Redondo y Eugenio Contreras Domingo. Madrid: Universidad Complutense, 2011. 209-217.

González Moreno, Fernando. «Historia gráfica de Poe: un siglo de ediciones ilustradas». Los legados de Poe. Ed. Margarita Rigal. Madrid: Síntesis, 2011. 107-144.

GonzÁLez Rodríguez, Luisa María. «La estética de la fragmentación y el collage en My Life de Lyn Hejinian». The Grove: Working Papers on English Studies 18 (2011): 53-68.

Gualberto Valverde, Rebeca. "'Himself armed with a lance': Mythologizing Transmigrant Experience in Paule Marshall's The Fisher King». Revista de estudios norteamericanos 15 (2011): 69-82.

Hernando-Real, Noelia. «My Home, My Battleground: the Deconstruction of the American Family». Performing Gender Violence: Plays by Contemporary American Women Writers. Eds. Barbara Ozieblo y Noelia Hernando-Real. Nueva York: Palgrave McMillan, 2011. 39-60.

- y Ozieblo, Barbara. «American Women Playwrights and Violence Against Women». Performing Gender Violence: Plays by Contemporary American Women Writers. Eds. Barbara Ozieblo y Noelia Hernando-Real. Nueva York: Palgrave McMillan, 2011. 27-38. 
Hoorvash, Mona y Pourgiv, Farideh. «Martha de Mimos: Femininity, Mimesis and Theatricality in Edward Albee's Who's Afraid of Virginia Woolf». Atlantis. Journal of the Spanish Association of Anglo-American Studies 33.2 (2011): 11-25.

HufF, Helen. «A Land of Despair and Change: Landscapes of Wealth and Poverty in Selected Plays of Naomi Wallace». Revista de estudios norteamericanos 15 (2011): 51-68.

Ibáñez IbÁÑ̃E, José R. «Killing the Beast at Home: Destroying Maternal Bonds in Moira Crone's 'The Ice Garden'». A View from the South: Contemporary English and American Studies. Eds. José R. Ibáñez Ibáñez y José Francisco Fernández Sánchez Almería: Editorial Universidad de Almería, 2011. 355-360.

— «Represión y Contrarrevolución en la China maoísta: la ficción breve de Ha Jin». A View from the South: Contemporary English and American Studies. Eds. José R. Ibáñez Ibáñez y José Francisco Fernández Sánchez Almería: Editorial Universidad de Almería, 2011. 361-367.

Ibarraran Bigalondo, Amaia. «Sandra Cisneros, Yxta Maya Murray, Michelle Serros: Three Decades, Three Ways. Some Examples of the 'Chicana Youth Esperience' in Literature». ES: Revista de Filología Inglesa 32 (2011): 147-160.

IbARrola Armendáriz, Aitor. «Broken Memories of a Traumatic Past and the Redemptive Power of Narrative in the Fiction of Edwidge Danticat». The Splintered Glass: Facets of Trauma in the Post-Colony and Beyond. Eds. M. Dolores Herrero y Sonia Baelo Allué. Amsterdam y Nueva York: Rodopi, 2011. 3-28.

— «Cormac McCarthy's The Road: Rewriting the Myth of the American West». European Journal of American Studies (2011). Revista electrónica.

- «David Guterson's The Other. The Doppelganger Tradition Visits the American North West». Beyond the Myth: New Perspectives on Western Texts. Eds. David Rio, Amaia Ibarraran y Martin Simonson. Londres: Portal, 2011. 29-48.

— «ZZ Packer's Drinking Coffee Elsewhere: A Serious Attempt at Representing the Diversity of th African-American Experience». Odisea: Revista de Estudios Ingleses 12 (2011): 137-148.

Junco Ezquerra, Víctor, Garrigós, Cristina, Fyfe, Daniel y Broncano, Manuel, eds. El 11 de septiembre y la tradición disidente en Estados Unidos. Biblioteca Javier Coy d'Estudis NordAmericans. Valencia: Universitat de València, 2011.

Lantigua Williams, Juleyka. «Interview with Junot Díaz»Camino real. Cuaderno de Hispanidades Norteamericanas 2 (2010): 195-204.

LAPRADE, Douglas Edward. Hemingway prohibido en España. Biblioteca Javier Coy d'Estudis Nord-Americans. Valencia: Universitat de València, 2011.

Liste Noya, José. «Memory in Motion: The 'Double Narratives' of Paul Auster's The Invention of Solitude and Samuel R. Delany's The Motion of Light in Water». Selves in Dialogue: A Transethnic Approach to American Life Writing. Ed. Begoña Simal. Amsterdam / Nueva York: Rodopi, 2011. 133-158.

- y Barros-Grela, Eduardo, eds. American Secrets: The Politics and Poetics of Secrecy in the Literature and Culture of the United States. Lanham, Maryland: Farleigh Dickinson University Press, 2011.

LÓPEz-RodríGuez, Miriam. «A Stalker, a Serial Killer, and the Women Who Survived Them: Psychological Abuse as a Form of Gender Violence». Performing Gender Violence: Plays by Contemporary American Women Writers. Eds. Barbara Ozieblo y Noelia Hernando-Real. Nueva York: Palgrave McMillan, 2011. 79-96.

LosAdA FrIEND, María. «Washington Irving and the Cult of Local Ireland in Oliver Goldsmith. A Biography». Glocal Ireland: Current Perspectives on Literature and the Visual Arts. Eds. Marisol Morales Ladrón y Juan F. Elices Agudo. Newcastle upon Tyne: Cambridge Scholars Publishing, 2011. 154-166. 
Manuel Cuenca, Carme. «Quilting Sculptural Knots: Lucille Clifton's Revisionary Rewriting». The Search for Wholeness and Diaspora Literacy in Contemporary African American Literature. Ed. Silvia Pilar Castro-Borrego. Newcastle upon Tyne: Cambridge Scholars Publishing, 2011. 107-130.

ManZanas, Ana M. ${ }^{a}$. «Self and Nation in Franklin's Autobiography and Maxine Hong Kingston's The Woman Warrior». Selves in Dialogue: A Transethnic Approach to American Life Writing. Ed. Begoña Simal. Amsterdam / Nueva York: Rodopi, 2011. 35-62.

Manzanas, Ana M. ${ }^{\mathrm{a}}$ y Benito, Jesús. Cities, Borders and Spaces in Intercultural American Literature and Film. Nueva York: Routledge, 2011.

Marín Ruiz, Ricardo. «Poe en la cultura popular». Los legados de Poe. Ed. Margarita Rigal. Madrid: Síntesis, 2011. 81-106.

- Tres visiones de España durante la guerra civil. 'L'espoir', 'Homage to Catalonia' y 'For Whom the Bell Tolls'. Murcia: Nausicaa, 2011.

Martin, Denise. «African American Women Writers as Medicine Women». The Search for Wholeness and Diaspora Literacy in Contemporary African American Literature. Ed. Silvia Pilar Castro-Borrego. Newcastle upon Tyne: Cambridge Scholars Publishing, 2011. 59-82.

Martín Gutiérrez, Félix. «Reto al futuro: frentes de rivalidad y venganza». Los legados de Poe. Ed. Margarita Rigal. Madrid: Síntesis, 2011. 203-220.

Martín-Lucas, Belén. «Burning Down the Little House on the Prairie: Asian Pioneers in Contemporary North American». Atlantis. Journal of the Spanish Association of AngloAmerican Studies 33.2 (2011): 27-41.

Martín PÁrraga, Javier. «Kurt Vonnegut: hacia una poética de la simplicidad». Alfinge: Revista de Filología 23 (2011): 201-216.

Martínez Illán, Antonio. «La influencia poética de Robert Frost sobre Joseph Brodsky». Espéculo. Revista de Estudios Literarios 46 (2010-11). Revista electrónica.

Mateos, Elisa. «Revision of American Indian Stereotypes and Post-Indian Identity in Sherman Alexie's Flight». Beyond the Myth: New Perspectives on Western Texts. Eds. David Rio, Amaia Ibarraran y Martin Simonson. Londres: Portal, 2011. 121-136.

Mickelli, Eftychia. «'Big empty Negroes' and 'gay, exciting' Mexicans: Recontextualizing Fellaheen Identities in Jack Kerouacs On the Road». Miscelánea: A Journal of English and American Studies 44 (2011): 53-70.

Miquel Baldellou, Marta. «Transatlantic Doubles: Intertextual Ageing in the Early Fiction of Edgar Allan Poe and Edward Bulwer-Lytton». Odisea: Revista de Estudios Ingleses 12 (2011): 149-164.

— «Twice-Told Traumas: Whatever Happened to Mary Rogers or Poe's Revenge on Life». ES: Revista de Filología Inglesa 32 (2011): 203-224.

Mitchell, Paul. Sylvia Plath. The Poetry of Negativity. Biblioteca Javier Coy d'Estudis NordAmericans. Valencia: Universitat de València, 2011.

Moreno, Marisel. «'Burlando la raza': la poesía de escritoras afrodominicanas en la diáspora» Camino real. Cuaderno de Hispanidades Norteamericanas 4 (2011): 169-194.

Moukouti Onguedou, Georges. «Interacción espacios -personajes en Nilda: análisis de las parejas actanciales». Espéculo. Revista de Estudios Literarios 46 (2010-11). Revista electrónica.

Narbona-Carrión, María Dolores. «The Role of Female Bonding on the Stage of Violence». Performing Gender Violence: Plays by Contemporary American Women Writers. Eds. Barbara Ozieblo y Noelia Hernando-Real. Nueva York: Palgrave McMillan, 2011. 61-78.

Nielsen, Aldon Lynn. «Kid Creole and His Beau-Coconauts: Lloyd Addison's Astro-Black Infinities». Revista canaria de estudios ingleses 62 (2011): 15-30.

Ozieblo, Barbara. «The Victim and the Audience's Pleasure: An Exploration of Carson Kreitzer's Self Defence and Stephanie Zadravec's Honey Brown Eyes». Performing Gender Violence: 
Plays by Contemporary American Women Writers. Eds. Barbara Ozieblo y Noelia HernandoReal. Nueva York: Palgrave McMillan, 2011. 155-172.

- Y Hernando-Real, Noelia, eds. Performing Gender Violence: Plays by Contemporary American Women Writers. Nueva York: Palgrave McMillan, 2011.

Pineda Hernández, Inmaculada. «A Celebration of Female Ancestors in Gloria Naylor's Mama Day». The Search for Wholeness and Diaspora Literacy in Contemporary African American Literature. Ed. Silvia Pilar Castro-Borrego. Newcastle upon Tyne: Cambridge Scholars Publishing, 2011. 131-150.

— «Survival Strategies in Recent Plays by African-American Women Playwrights». Performing Gender Violence: Plays by Contemporary American Women Writers. Eds. Barbara Ozieblo y Noelia Hernando-Real. Nueva York: Palgrave McMillan, 2011. 113-130.

Piqueras Cabrerizo, Belén. «Bill Brown's 'Thing Theory' and the Quest of Unique Epistemology in Modernist and Postmodernist Literature: a Study of Don DeLillo's White Noise». ES: Revista de Filología Inglesa 32 (2011): 263-282.

— «Las metáforas provisionales de la postmodernidad: la obra de William Gass». Miscelánea: A Journal of English and American Studies 44 (2011): 71-86.

Quintana Millamoto, M. ${ }^{a}$ Esther. «Los hilos sueltos de la historia: Caramelo, or, Puro Cuento». Camino real. Cuaderno de Hispanidades Norteamericanas 5 (2011): 127-150.

RAMÓN, Emilio. «Funnyhouse of a Negro: Rejection of Womanness and Blackness as a 'Melancholic' Cry for a True Diversity in American Society». ES: Revista de Filología Inglesa 32 (2011): 283-300.

Rampton, David. «The Ethical Turn. Ageing in Late Roth». Acculturating Age. Approaches to Cultural Gerontology. Ed. Brian J. Worsfold. Lleida: University of Lleida, 2011. 297-312.

Rigal, Margarita. «La ciencia del raciocinio». Los legados de Poe. Ed. Margarita Rigal Madrid: Síntesis, 2011. 37-61.

— «Lo gótico y lo cómico». Los legados de Poe. Ed. Margarita Rigal. Madrid: Síntesis, 2011. 17-36.

— , ed. Los legados de Poe. Madrid: Síntesis, 2011.

- y Galdón RodríGuez, Ángel. «Anexo III: Estudio bibliográfico». Los legados de Poe. Ed. Margarita Rigal. Madrid: Síntesis, 2011. 273-288.

— , Galdón Rodríguez, Ángel y Marín Ruiz, Ricardo. «Anexo III: Estudio bibliográfico». Los legados de Poe. Ed. Margarita Rigal. Madrid: Síntesis, 2011. 273-288.

- y Marín Ruiz, Ricardo. «Anexo II: Estudio de las obras del autor». Los legados de Poe. Ed. Margarita Rigal. Madrid: Síntesis, 2011. 227-272.

Río, David. «Autobiographical Writing on Politics in the Sin State: Latina and Basque American Perspectives». Selves in Dialogue: A Transethnic Approach to American Life Writing. Ed. Begoña Simal. Amsterdam / Nueva York: Rodopi, 2011. 159-180.

— «Reconsidering Western Writing Beyond the Regional Imaginary and its Mythic Borders». Beyond the Myth: New Perspectives on Western Texts. Eds. David Rio, Amaia Ibarraran y Martin Simonson. Londres: Portal, 2011. xiii-xxiii.

- y Hestetun Øyunn. «Introduction: Storying the West in Postfrontier Literature». European Journal of American Studies (2011). Revista electrónica.

- , Ibarraran, Amaia y Simonson, Martin, eds. Beyond the Myth: New Perspectives on Western Texts. Londres: Portal, 2011.

Rodríguez Guerrero-Strachan, Santiago. «'By his own thought and feeling’: la imaginación creadora de Wallace Stevens y José Ángel Valente». A View from the South: Contemporary English and American Studies. Eds. José R. Ibáñez Ibáñez y José Francisco Fernández Sánchez Almería: Editorial Universidad de Almería, 2011. 75-80. 
— «Un persistente recuerdo: la recepción de Poe en España». Los legados de Poe. Ed. Margarita Rigal. Madrid: Síntesis, 2011. 145-174.

RodríGuez Herrera, José Manuel. «A Boundary-Dissolving Binding: The Eclectic Composition Underlying the First Edition of Leaves of Grass». Revista de estudios norteamericanos 15 (2011): 83-100.

Rollason, Christopher. «Edgar Allan Poe, Julio Cortázar and Paris: A Study in Doubling». A View from the South: Contemporary English and American Studies. Eds. José R. Ibáñez Ibáñez y José Francisco Fernández Sánchez Almería: Editorial Universidad de Almería, 2011. 81-85.

— «Poe's 'A Tale of the Ragged Mountains,' Macaulay and Warren Hastings: From Orientalism to Globalisation?». India in the World. Eds. Cristina Gámez-Fernández y Antonia NavarroTejero. Newcastle upon Tyne: Cambridge Scholars Publishing, 2011. 109-120.

Rutsala, Kirsten. «Nabokov's Dialogue with Chekhov: Ladies with and without Dogs». Anuari de Filologia. Llengües Modernes 1 (2011): 33-42.

Salmerón, Julia. "'Yes, I'm goin to Europe to make a mint': The Painful Journey of Saartjie Baartman and Suzan-Lori Parks's Venus». She's Leaving Home, Women's Writing in English in a European Context. Eds. Nóra Séllei y June Waudby. Berna: Peter Lang, 2011. 41-52.

SÁnchez Gómez, M. ${ }^{a}$ Soledad. "'Qué es ser una mujer?': histeria y posmodernidad en A Streetcar Named Desire». Epos: Revista de Filología 27 (2011): 223-232.

SÁnchez NAfFziger, Juan. «Divine Communications in a Time of Revival: Jonathan Edwards' Use of Light and Water Imagery during the Northampton Revival, 1734-35». Revista de estudios norteamericanos 15 (2011): 11-32.

SAnderson, John D. «The Shadow over Galicia: H. P. Lovecraft's Obsessions Resurface in the Film Adaptation of Dagon (2001)». Odisea: Revista de Estudios Ingleses 12 (2011): 245-256.

San José Rico, Patricia y Mezquita Fernández, María Antonia. «Escaping Trauma through a Dreamworld: Fantasy and the Evasion of Pain in Jane Yolen's Briar Rose and John Boyne's The Boy in the Striped Pyjamas». ES: Revista de Filología Inglesa 32 (2011): 301-316.

Santos Vila, Sonia, ed. y trad. Ambrose Bierce: Cartas escogidas. Barcelona, Ediciones Rubeo, 2011.

SEguro, María Isabel. "'Such is the cost of my belonging, molding to whatever is at hand:' Citizenship, Americanness, and Asian American Masculinity in A Gesture Life». Men in Color: Racialized Masculinities in U.S. Literature and Cinema. Ed. Josep M. Armengol. Newscatle upon Tyne: Cambridge Scholars Publishing, 2011. 79-100.

Simal GonZÁlez, Begoña. «The Challenge of Going Transethnic: Exploring American Autobiography in the Twenty-First Century». Revista de estudios norteamericanos 15 (2011): 33-50.

— , ed. Selves in Dialogue: A Transethnic Approach to American Life Writing. Amsterdam / Nueva York: Rodopi, 2011.

Shafer, Yvonne. Eugene O'Neill and American Society. Biblioteca Javier Coy d'Estudis NordAmericans. Valencia: Universitat de València, 2011.

Tschachler, Heinz. «Paper, Silver, Gold; or, Edgar Allan Poe and the Question of America's Money». A View from the South: Contemporary English and American Studies. Eds. José R. Ibáñez Ibáñez y José Francisco Fernández Sánchez Almería: Editorial Universidad de Almería, 2011. 435-442.

Torreiro Pazo, Paula. «Living in the Taste of Things: Food, Self and Family in Diana AbuJaber's The Language of Baklava and Leslie Li's Daughter of Heaven». Selves in Dialogue: A Transethnic Approach to American Life Writing. Ed. Begoña Simal. Amsterdam / New York: Rodopi, 2011. 207-232.

Twain, Mark. Sobre la religión. Ed. y trad. Sonia Santos Vila. Madrid: Ediciones Sequitur, 2011. VAN NyHUIS, Alison. «American Dreams and Nightmares: Migration and Myth in Claude McKay's Twentieth-Century American Poetry». Revista canaria de estudios ingleses 62 (2011): 31-42. 
Van-Peteghem Tréard, Isabelle. "Womanism, Sexual Healing and the Suture of Ecospirituality in Alice Walker's Novels: From Meridian to Now Is the Time to Open Your Heart». The Search for Wholeness and Diaspora Literacy in Contemporary African American Literature. Ed. Silvia Pilar Castro-Borrego. Newcastle upon Tyne: Cambridge Scholars Publishing, 2011. 19-40.

VÁzquez Negro, Rubén. Sam Shepard: el teatro contra sí mismo. Biblioteca Javier Coy d'Estudis Nord-Americans. Valencia: Universitat de València, 2011.

Vega GonzÁlez, Susana. «'A perfect seam': Autobiographical Traits in Toni Morrison's Fiction». The Grove: Working Papers on English Studies 18 (2011): 105-122.

Yebra, José María. «Go West: from the Homosocial to the Homosexual in Annie Proulx's Brokeback Mountain». A View from the South: Contemporary English and American Studies. Eds. José R. Ibáñez Ibáñez y José Francisco Fernández Sánchez Almería: Editorial Universidad de Almería, 2011. 375-380.

ZÚÑIga LóPez, Gabriela Karina. «Breve lectura de Moby Dick desde la poética del agua de Bachelard». Espéculo. Revista de Estudios Literarios 46 (2010-11). Revista electrónica. 


\section{OTRAS LITERATURAS EN LENGUA INGLESA}

\section{DídAC LloRens Cubedo}

UNED. Madrid

dllorens@flog.uned.es

\section{Estudios SObre Literatura Africana}

Ballesteros González, Antonio. «Retratos del artiste manqué: influencia de James Joyce en las obras autobiográficas de J. M. Coetzee». A View from the South: Contemporary English and American Studies. Eds. José R. Ibáñez Ibáñez y José Francisco Fernández Sánchez Almería: Editorial Universidad de Almería, 2011. 47-53.

Martín Matas, Patricia. «La interacción entre lengua y cultura Igbo en la novela de Achebe Things Fall Apart». Espéculo. Revista de Estudios Literarios 46 (2010-11). Revista electrónica.

Onega, Susana. «J. M. Coetzee's In the Heart of the Country». The Splintered Glass: Facets of Trauma in the Post-Colony and Beyond. Eds. M. Dolores Herrero y Sonia Baelo Allué. Amsterdam y Nueva York: Rodopi, 2011. 101-134.

PÉREZ Ruiz, Bibian. Lo lejano y lo bello: feminismos y maternidades africanas a través de su literatura. Madrid: Fundamentos, 2011.

- «The Rising Colour of Sisterhood in African Literature: The Purple Violet of Oshaantu (2001) and Purple Hibiscus (2004)». The Grove: Working Papers on English Studies 18 (2011): 125-142.

\section{Estudios SOBRE Literatura India / Asiática}

Blanco-CARrión, Olga. «Framing Interpersonal Violence in A Married Woman». India in the World. Eds. Cristina Gámez-Fernández y Antonia Navarro-Tejero. Newcastle upon Tyne: Cambridge Scholars Publishing, 2011. 143-156.

GÁmeZ-FernándeZ, Cristina M. «Identity in Jhumpa Lahiri’s The Namesake». India in the World. Eds. Cristina Gámez-Fernández y Antonia Navarro-Tejero. Newcastle upon Tyne: Cambridge Scholars Publishing, 2011. 157-162.

- «Transparency and Depth: An Interview with Kiran Nagarkar». Revista canaria de estudios ingleses 62 (2011): 139-148.

- y Navarro-Tejero, Antonia, eds. India in the World. Newcastle upon Tyne: Cambridge Scholars Publishing, 2011.

García SAnZ, Emma. «The Search for Female Identity in R. K. Narayan's The Dark Room». India in the World. Eds. Cristina Gámez-Fernández y Antonia Navarro-Tejero. Newcastle upon Tyne: Cambridge Scholars Publishing, 2011. 163-172.

HAND, Felicity. «From Inscrutable Indians to Asian Africans». India in the World. Eds. Cristina Gámez-Fernández y Antonia Navarro-Tejero. Newcastle upon Tyne: Cambridge Scholars Publishing, 2011. 75-86. 
Ibarrola Armendáriz, Aitor. «The Dwindling Presence of Indian Culture and Values in Jumpa Lahiri's Unaccustomed Earth». ES: Revista de Filología Inglesa 32 (2011): 161-178.

López, Maria J. "'She had been certain the river would sustain her': Modernist Aestheticism in Anita Desai's Fiction». India in the World. Eds. Cristina Gámez-Fernández y Antonia Navarro-Tejero. Newcastle upon Tyne: Cambridge Scholars Publishing, 2011. 173-182.

Martín PÁrRaga, Javier. «Manju Kapur's Difficult Daughters and the Deconstruction of Traditional Binary Oppositions». India in the World. Eds. Cristina Gámez-Fernández y Antonia NavarroTejero. Newcastle upon Tyne: Cambridge Scholars Publishing, 2011. 183-190.

Martos Hueso, María Elena. "Amitav Ghosh's 'Imaginary Homelands': The Question of Identity in The Shadow Lines». India in the World. Eds. Cristina Gámez-Fernández y Antonia Navarro-Tejero. Newcastle upon Tyne: Cambridge Scholars Publishing, 2011. 191-202.

O'ConNor, Maurice. «A Paradise Lost: Kashmir as a Motif of Rift in Salman Rushdie's Shalimar the Clown». India in the World. Eds. Cristina Gámez-Fernández y Antonia Navarro-Tejero. Newcastle upon Tyne: Cambridge Scholars Publishing, 2011. 211-220.

Oliva, Juan Ignacio. "'Indias in Mind': The Literary Recovery of Absent India». India in the World. Eds. Cristina Gámez-Fernández y Antonia Navarro-Tejero. Newcastle upon Tyne: Cambridge Scholars Publishing, 2011. 87-98.

Peco González, Laura. «The Redefinition of the Concept 'Anglo-Indian' in Contemporary Narrative». India in the World. Eds. Cristina Gámez-Fernández y Antonia Navarro-Tejero. Newcastle upon Tyne: Cambridge Scholars Publishing, 2011. 101-108.

Reyes Torres, Agustín. «Roy's Inglish in The God of Small Things: A Language for Subversion, Reconciliation and Reassertion». Odisea: Revista de Estudios Ingleses 12 (2011): 195-204.

Villa Jiménez, Rosalía. «Sati: A Construction of Reality in With Krishna's Eyes». India in the World. Eds. Cristina Gámez-Fernández y Antonia Navarro-Tejero. Newcastle upon Tyne: Cambridge Scholars Publishing, 2011. 277-288.

\section{Estudios sobre Literatura Australiana y Neocelandesa}

ARIzTI, Bárbara. «Personal Trauma/Historical Trauma in Tim Winton's Dirt Music». The Splintered Glass: Facets of Trauma in the Post-Colony and Beyond. Eds. M. Dolores Herrero y Sonia Baelo Allué. Amsterdam y Nueva York: Rodopi, 2011. 175-190.

Baines Alarcos, M. ${ }^{a}$ Pilar. «Jack Maggs: The Use of Hypnotism at the Dusk of the British Empire». Revista canaria de estudios ingleses 63 (2011): 53-64.

FraILE, Isabel. «Inside Out in the Land Down Under: Reading Trauma through Janette Turner Hospital's Oyster». The Splintered Glass: Facets of Trauma in the Post-Colony and Beyond. Eds. M. Dolores Herrero y Sonia Baelo Allué. Amsterdam y Nueva York: Rodopi, 2011. 221-244.

Fresno Calleja, Paloma. «Femenino y plural: sub/versiones del paraíso en la poesía de Tusiata Avia». Babel afial: Aspectos de filología inglesa y alemana 20 (2011): 5-20.

Martin Renes, Cornelis. «Caught in-between: Mudrooroo's Vexed Deconstruction of Australianness». A View from the South: Contemporary English and American Studies. Eds. José R. Ibáñez Ibáñez y José Francisco Fernández Sánchez Almería: Editorial Universidad de Almería, 2011. 293-299.

Rodríguez Salas, Gerardo y Andrés-Cuevas, Isabel María. The Aesthetic Construction of the Female Grotesque in Katherine Mansfield and Virginia Woolf: A Study of the Interplay of Life and Literature. Lewiston, Nueva York: The Edwin Mellen Press, 2011.

Serra Pagés, Carles Conrad. «'Hospitality' and Postcolonial Australia». A View from the South: Contemporary English and American Studies. Eds. José R. Ibáñez Ibáñez y José Francisco Fernández Sánchez Almería: Editorial Universidad de Almería, 2011. 300-306. 


\section{Estudios Sobre Literatura Canadiense}

Carbajosa Pérez, Mónica. «Alice Munro: el dominio del cuento». Espéculo. Revista de Estudios Literarios 46 (2010-11). Revista electrónica.

Cuder-Domínguez, Pilar, Martín-Lucas, Belén, and S. Villegas-López. Transnational Poetics: Asian Canadian Women's Fiction of the 1990s. Toronto: TSAR, 2011.

Hernáez Lerena, M. a Jesús. «Transforming the Wilderness into God's Creation: John James Audubon in a Canadian Space». Miscelánea: A Journal of English and American Studies 44 (2011): 33-52.

\section{Estudios SOBRe Literatura CARiBeÑA}

Alonso Alonso, María. «The Woman that Turned into a Ball of Fire and Whipped Across the Sky at Night: Recreating History and Memory in the Diaspora». Journal of English Studies 9 (2011): 13-28.

Condobés, Fernando. «La otra Trinidad de Samuel Selvon». Cuadernos hispanoamericanos 727 (2011): 45-50.

Escudero, Maite. «'Softer than Cotton, Stronger than Steel': Metaphor and Trauma in Shani Mootoo's Cereus Blooms at Night». The Splintered Glass: Facets of Trauma in the PostColony and Beyond. Eds. M. Dolores Herrero y Sonia Baelo Allué. Amsterdam y Nueva York: Rodopi, 2011. 135-152.

Fernández Merino, Mireya. «El extranjero de las mil caras: su representación en las literaturas del Caribe y sus diásporas». 1616. Anuario de la Sociedad Española de Literatura General y Comparada 1 (2011): 65-84.

Galindo, Alberto S. «Less 9/11 Is More 9/11: The Brief Wondrous Life of Oscar Wao and A Day a Night and a Day». Cultura, lenguaje y representación (Culture, Language and Representation) 9 (2011): 81-97.

Ibarrola Armendáriz, Aitor. «Puerto Rican and Dominican Self-Portraits and their Frames: The 'Autobiographical' Fiction of Esmeralda Santiago, Junot Díaz, and Julia Álvarez». Selves in Dialogue: A Transethnic Approach to American Life Writing. Ed. Begoña Simal. Amsterdam / Nueva York: Rodopi, 2011. 181-206. 


\title{
D. ENFOQUES TEÓRICOS O GENERALISTAS
}

\author{
DídAC Llorens Cubedo \\ UNED. Madrid \\ dllorens@flog.uned.es
}

Armengol, Josep M., ed. Men in Color: Racialized Masculinities in U.S. Literature and Cinema. Newcastle upon Tyne: Cambridge Scholars Publishing, 2011.

Attridge, Derek. La singularidad de la literatura. Ed. María Jesús López Sánchez-Vizcaíno. Madrid: Abada Editores, 2011.

BARros Grela, Eduardo. «Web 2.0: Narrativas y espacios digitales. Inteligencia colectiva en blogs, wikis y plataformas desde un entorno culturalista». Oceánide 3 (2011). Revista electrónica.

Bennett, Karen. «Plagiarism Reassessed: A Culturalist Take on Academia's Capital Sin». The European English Messenger 20.1 (2011): 74-77.

— «Small Press Publishing: Absorbing New Forms, Circulating New Ideas». Revista canaria de estudios ingleses 62 (2011): 9-14.

BRITO, Manuel. «The Impact of the Poet-Editor: Some Questions». Revista canaria de estudios ingleses 62 (2011): 81-98.

BudziaK, Anna. «Of Mirrors and Multiversity, Doppelgängers and Doppelgängerins». The European English Messenger 20.2 (2011): 47-54.

Bureu-Ramos, Nela. «Our Pathway to Age and the Holding Action of Art». Acculturating Age. Approaches to Cultural Gerontology. Ed. Brian J. Worsfold. Lleida: University of Lleida, 2011. 153-166.

Castro Borrego, Silvia y Romero Ruiz, Maria Isabel, eds. Cultural Migrations and Gendered Subjects: Colonial and Postcolonial Representations of the Female Body. Newcastle upon Tyne: Cambridge Scholars Publishing, 2011.

— «Introduction: Repossesssing Our Bodies and Ourselves». Cultural Migrations and Gendered Subjects: Colonial and Postcolonial Representations of the Female Body. Eds. Silvia Castro Borrego y María Isabel Romero Ruiz. Newcastle upon Tyne: Cambridge Scholars Publishing, 2011. 1-12.

De Toro Santos, Antonio Raúl, ed. Music in Modern Irish Literature. A Coruña: Netbiblo, 2011.

Flys Junquera, Carmen. «Dissolving the False Divide: Literary Strategies for Re-situating Humans Ecologically and Non-humans Ethically». Revista canaria de estudios ingleses 63 (2011): 21-38.

GonZÁlez-Rivas Fernández, Ana. «Lo clásico y lo gótico: origen estético y conceptual de una tensión literaria». A View from the South: Contemporary English and American Studies. Eds. José R. Ibáñez Ibáñez y José Francisco Fernández Sánchez Almería: Editorial Universidad de Almería, 2011. 54-60.

Herrero, M. Dolores y Baelo Allué, Sonia, eds. The Splintered Glass: Facets of Trauma in the Post-Colony and Beyond. Amsterdam / Nueva York: Rodopi, 2011.

IbáÑez Ibáñez, José R. y Fernández Sánchez, José Francisco, eds. A View from the South: Contemporary English and American Studies. Almería: Editorial Universidad de Almería, 2011.

Martín Alegre, Sara. Desafíos a la heterosexualidad obligatoria. Barcelona: Ediuoc, 2011. 
MaZIARCZYK, Grzegorz. "Between the Scylla of Theory and the Charybdis of Practice: The Peculiar Case of a Frame Narrative». Revista canaria de estudios ingleses 63 (2011): 127-130.

McElroy, James. «Ecocriticism and Irish Poetry: A Preliminary Outline». Estudios Irlandeses 6 (2011): 54-69.

Morales Ladrón, Marisol and Elices Agudo, Juan F., eds. Glocal Ireland: Current Perspectives on Literature and the Visual Arts. Newcastle: Cambridge Scholars Publishing, 2011.

— «Introduction: The Politics of Glocality». Glocal Ireland: Current Perspectives on Literature and the Visual Arts. Eds. Marisol Morales Ladrón y Juan F. Elices Agudo. Newcastle upon Tyne: Cambridge Scholars Publishing, 2011. 1-10.

Navarro-Tejero, Antonia. «A Brief Overview on Feminism in India». India in the World. Eds. Cristina Gámez-Fernández y Antonia Navarro-Tejero. Newcastle upon Tyne: Cambridge Scholars Publishing, 2011. 257-264.

O'Leary, Catherine y Lázaro Alberto, eds. Censorship across Borders: The Reception of English Literature in Twentieth-Century Europe. Newcastle upon Tyne: Cambridge Scholars Publishing, 2011.

Redondo-Olmedilla, José Carlos. «Rasgos e identidad de la literatura comparada en tiempos de cambio». A View from the South: Contemporary English and American Studies. Eds. José R. Ibáñez Ibáñez y José Francisco Fernández Sánchez Almería: Editorial Universidad de Almería, 2011. 68-74.

Romero Ruiz, María Isabel. «Gender Policy, the London Lock Asylum Committee (1836-1842) and the Asylum Regulations for 1840». Atlantis. Journal of the Spanish Association of AngloAmerican Studies 33.2 (2011): 123-136.

Sánchez-Palencia Carazo, Carolina y Almagro, Manuel. «Fast Forward to the Past: Revisiting Trauma after the Fall». Miscelánea: A Journal of English and American Studies 44 (2011): 121-136.

Tötösy De ZePetneK, Steven. «Synopsis of the Current Situation of Comparative Humanities in the U.S and Europe». $452^{\circ}$ F: Revista de Teoría de la Literatura y Literatura Comparada 5 (2011): 13-31.

VAlero Garcés, Carmen. «Ecocriticism and Translation». Odisea: Revista de Estudios Ingleses 12 (2011): 257-272. 


\title{
E. ESTUDIOS DE TRADUCCIÓN
}

\author{
José JAVIER Ávila CABRERA \\ UNED. MADRID \\ javila@flog.uned.es
}

Aguirre Oteiza, Daniel. «Encrucijadas de los modernismos anglosajón e hispanoamericano sobre traducción y tradición en la poesía de W. B. Yeats». 1611: revista de historia de la traducción 5 (2011): 1-4.

Akbatur, Arzu. «Turkish Women Writers in English Translation». MonTI 3 (2011): 161-179.

Ándujar Moreno, Gemma y Cañada Pujols, María Dolores. «El enfoque por tareas en la didáctica de la traducción jurídica: propuesta de aplicación práctica». Estudios de traducción 1 (2011): 185-204.

Aragonés Lumeras, Maite. «El traductor de patentes: de Sherlock Holmes a James Bond». Panace@: Revista de Medicina, Lenguaje y Traducción 12.33 (2011): 102-10.

Barambones Zubiria, Josu. «Una mirada telescópica al cine en euskera: Versiones originales, dobladas y subtituladas». Hermeneus: Revista de la Facultad de Traducción e Interpretación de Soria 13 (2011): 25-59.

Braga Riera, Jorge. «¿Traducción, adaptación o versión?: maremágnum terminológico en el ámbito de la traducción dramática». Estudios de traducción 1 (2011): 59-72.

- «Women in Contemporary English Drama Translation: Enhancement and Downplay Mechanisms to Portray Golden Age Damas». MonTI 3 (2011): 231-255.

Brufau Alvira, Nuria. «Traducción y género: El estado de la cuestión en España». MonTI 3 (2011): 181-207.

CAdera, Susanne. «Reflexiones sobre la traducción de la oralidad fingida en la narrativa». Traducción e interpretación: estudios, perspectivas y enseñanzas. Coord. María Luisa Romana García, José Manuel Sáenz Rotko, Pilar Úcar Ventur. Madrid: Universidad Pontificia Comillas, 2011. 37-58.

Calvo Encinas, Elisa, Enríquez Aranda, María Mercedes, Jiménez Carra, Nieves, Mendoza García, Inmaculada, Morón Martín, Marián y Ponce Márquez, Nuria, eds. La traductología actual: nuevas vías de investigación en la disciplina. Granada: Comares, 2011.

Calzada Pérez, María. «Una aproximación empírica a la clasificación y traducción de las figuras retóricas en la publicidad». Babel 57.1 (2011): 32-57.

CAmps, Assumpta. «'A mitad de camino entre aquí y allá, en medio de quién sabe dónde’: Traducir la/desde la frontera». MonTI 3 (2011): 337-354.

Camus Camus, María del Carmen. «Women, Translation and Censorship in the Franco Regime». MonTI 3 (2011): 447-470.

Costa-Jussá, Marta R., Henríquez, Carlos y Banchs, Rafael. «Evaluación de estrategias para la traducción automática estadística de chino a castellano con el inglés como lengua pivote». Procesamiento del lenguaje natural 47 (2011): 119-126.

Dasilva, Xosé Manuel, y TANQueiro, Helena, eds. Aproximaciones a la autotraducción. Vigo: Academia del Hispanismo, 2011.

De la Riva Fort, José Antonio. «Cuatro herramientas para cuatro actividades profesionales. Recursos de Microsoft Word para la redacción, traducción, corrección y revisión de documentos especializados».Panace@: Revista de Medicina, Lenguaje y Traducción 33 (2011): 83-97. 
Duro Moreno, Miguel. «El modelo de los entornos de la traducción: fundamentos teóricos básicos y aplicaciones didácticas posibles a la traducción jurídica (Inglés $>$ Español)». Traducción e interpretación: estudios, perspectivas y enseñanzas. Coord. María Luisa Romana García, José Manuel Sáenz Rotko, Pilar Úcar Ventura. Madrid: Universidad Pontificia Comillas, 2011. 59-70.

Elena, Pilar. «El aprendizaje activo en traducción y su evaluación». Estudios de traducción 1 (2011): 171-183.

— «La carpeta de aprendizaje en traducción». Traducción e interpretación: estudios, perspectivas y enseñanzas. Coord. María Luisa Romana García, José Manuel Sáenz Rotko, Pilar Úcar Ventura. Madrid: Universidad Pontificia Comillas, 2011. 71-84.

Even-Zohar, Itamar. «'Textemas' vs. 'repertoremas' en la traducción». Tópicos del Seminario 25 (2011): 77-84.

FAYA ORNIA, Goretti. «Comparativa de herramientas empleadas para mejorar la comunicación con pacientes extranjeros en centros sanitarios del Reino Unido, Alemania y España». Sendebar 22 (2011): 191-208.

FedERICI, Eleonora. «Metaphors in Dialogue: Feminist Literary Critics, Translators and Writers». MonTI 3 (2011): 355-376.

Fernádez Polo, Francisco Javier y Cal Varela, Mario. «Learning translation through the use of Portfolios: Description of an Experience». @ tic. Revista d'innovació educativa 7 (2011): 44-51.

Fernández Rodríguez, Carmen M. ${ }^{\mathrm{a}}$ "A Genevan Camilla: The First Translation of Frances Burney's Camilla into French». The Grove: Working Papers on English Studies 18 (2011): 225-242.

Fouces González, Covadonga Gemma. La traducción literaria y la globalización de los mercados culturales. Granada: Comares, 2011.

- «Mapas de traducción en Europa. La ficción narrativa comercial en Italia y España». TRANS 15 (2011): 117-130.

FuJINo, Hanako. «Hacia una enseñanza 'USER-FRIENDLY'». Traducción e interpretación: estudios, perspectivas y enseñanzas. Coord. María Luisa Romana García, José Manuel Sáenz Rotko, Pilar Úcar Ventura. Madrid: Universidad Pontificia Comillas, 2011. 85-92.

García Aguiar, Livia Cristina y García Jiménez, Rocío. «La influencia del sistema meta en traducción: el doblaje de Los Picapiedra al español neutro». Estudios de traducción 1 (2011): 127-138.

García CALderón, Ángeles. «Ivanhoe traducido al español: análisis contrastivo de tres versiones». The Grove: Working Papers on English Studies 18 (2011): 201-224.

García De Fórmica-Corsi, David. «La traducción de la repetición en 'The Nightingale and the Rose', de Oscar Wilde». TRANS 15 (2011): 171-191.

García IzQuierdo, Isabel. Competencia textual para la traducción. Valencia: Tirant Lo Blanch, 2011. 163-173.

García Vizcaíno, M. ${ }^{a}$ José. «La traducción de anuncios multilingües: un reto para el traductor del siglo XXI». Babel 57.2 (2011): 185-203.

González Iglesias-González, Juan David. "Análisis diacrónico de la velocidad de presentación de subtítulos para DVD». TRANS 15 (2011): 211-218.

GonzÁlez Rodríguez, Luisa María. «Reflexiones sobre la traducción al español de los parlamentos dialectales en la novela Sons and Lovers de D. H. Lawrence». Hermeneus: Revista de la Facultad de Traducción e Interpretación de Soria 13 (2011): 61-82.

González Vera, Pilar. «Translating Images: the Impact of the Image on the Translation of Disney's Alice in Wonderland into Spanish». Miscelánea: A Journal of English and American Studies 43 (2011): 33-54.

Grossman, Edith y Gandolfo, Elvio E. Por qué la traducción importa. Madrid: Katz, 2011. 
Hassen, Rim. «English Translation of the Quran by Women: The Challenges of 'Gender Balance' in and through Language». MonTI 3 (2011): 211-230.

Huertas Abril, Cristina. «'The Warwickshire Circle' a través de la correspondencia de Lady Luxborough: estudio y traducción de las cartas». Alfinge 23 (2011): 107-128.

JEFFREY, Susan. «Competences for Advanced Language Learners». Traducción e interpretación: estudios, perspectivas y enseñanzas. Coord. María Luisa Romana García, José Manuel Sáenz Rotko, Pilar Úcar Ventura. Madrid: Universidad Pontificia Comillas, 2011. 109-120.

JoRDAN NúÑEZ, Kenneth. «Análisis contrastivo de la demanda o 'claim' como tipo textual». Hermeneus: Revista de la Facultad de Traducción e Interpretación de Soria 13 (2011): 83-102.

Keller, Nicole. «La traducción de textos médicos especializados, ilustrada mediante el par de idiomas inglés-alemán».Panace@: Revista de Medicina, Lenguaje y Traducción 12.34 (2011): 234-239.

Leonardi, Vanessa y Taronna, Annarita. «Translators vs Translatresses' Strategies: Ethical and Ideological Challenges». MonTI 3 (2011): 377-402.

LINDER, Daniel. «Traducciones del clásico Chandler publicadas por Barral Editores (Barcelona)». 1611: revista de historia de la traducción 5 (2011).

Mangiron Hevia, Carme. «Accesibilidad a los videojuegos: estado actual y perspectivas futuras». TRANS 15 (2011): 53-67.

Marco Tobarra, José María. «Traductores y traducción en el Quijote». Traducción e interpretación: estudios, perspectivas y enseñanzas. Coord. María Luisa Romana García, José Manuel Sáenz Rotko, Pilar Úcar Ventura. Madrid: Universidad Pontificia Comillas, 2011. 121-134.

Martín, Silke Anne. «El modelo de un comentario traslativo guiado como método de autorreflexión para la enseñanza de la traducción». Babel afial: Aspectos de filología inglesa y alemana 20 (2011): 87-101.

Martín Matas, Patricia. «Propuesta para desarrollar las competencias relacionadas con los conocimientos de informática dentro de los grados de traducción adaptados al EEES». Traducción e interpretación: estudios, perspectivas y enseñanzas. Coord. María Luisa Romana García, José Manuel Sáenz Rotko, Pilar Úcar Ventura. Madrid: Universidad Pontificia Comillas, 2011. 135-142.

Martínez García, Eva María. «Los 'Fansubs': el caso de traducciones (no tan) amateur». Tonos Digital: Revista Electrónica de Estudios Filológicos 20 (2011).

Martínez Sierra, Juan José. «De normas, tendencias y otras regularidades en traducción audiovisual». Estudios de traducción 1 (2011): 151-170.

Molina Martínez, Lucía. «La traducción de noticias como soporte icónico: la imagen como referente cultural». Sendebar 22 (2011): 73-86.

Molina Plaza, Silvia. «Luces y sombras en las traducciones de Narraciones extraordinarias y Poesía completa». Los legados de Poe. Ed. Margarita Rigal. Madrid: Síntesis, 2011. 187-202.

Montero Martínez, Silvia, Faber Benítez, Pamela y Buendía Castro, Miriam. Terminología para traductores e intérpretes, una perspectiva integradora. $2^{\mathrm{a}}$ ed. Granada: Tragacanto, 2011.

Moré López, Joaquín y Climent Roca, Salvador. «La noción de tradautomaticidad en la traducción automática. Anuari de Filologia. Estudis de Lingüística 1 (2011): 135-166.

Mugüerza Pecker, Pablo A., Barbetti Bros, Lida y Gallego-Borghini, Lorenzo. «Glosario crítico inglés-español de documentos de consentimiento informado».Panace@: Revista de Medicina, Lenguaje y Traducción 12.33 (2011): 19-34.

Muñoz MuÑoz, José Manuel y Vella Ramírez, Mercedes. «Intención comunicativa y nombres propios en la traducción española de Porterhouse Blue». TRANS 15 (2011): 155-170.

Nimmo, Clare Elizabeth. «The Art of Translating Press Releases». Traducción e interpretación: estudios, perspectivas y enseñanzas. Coord. María Luisa Romana García, José Manuel Sáenz Rotko, Pilar Úcar Ventura. Madrid: Universidad Pontificia Comillas, 2011. 179-190. 
Ortega Herráez, Juan Miguel. «Cómo acreditar intérpretes a través de la traducción: análisis crítico de la acreditación profesional de intérpretes jurídicos en España». TRANS 15 (2011): 131-153.

Perales Escudero, Moisés y Swales, John M. «Tracing Convergence and Divergence in Pairs of Spanish and English Research Article Abstracts: The Case of Ibérica». Ibérica: Revista de la Asociación Europea de Lenguas para Fines Específicos 21 (2011): 49-70.

Pursglove, Glyn. «Falsificación, diversión y cambio cultural: algunos de los motivos del pseudotraductor». Hermeneus: Revista de la Facultad de Traducción e Interpretación de Soria 13 (2011): 151-176.

RALUY AlONSO, Ángel. «Las palabras trabajar y trabajo en español peninsular e inglés americano: dos visiones cultural, etimológica y semánticamente diferentes». Tonos digital: Revista electrónica de estudios filológicos 21 (2011): 1.

Recuenco PeÑalver, María. «Más allá de la traducción: la autotraducción». TRANS 15 (2011): 193-208.

Rodríguez Rodríguez, Beatriz María. «La traducción literaria: nuevos retos didácticos». Estudios de traducción 1 (2011): 25-37.

Romana García, María Luisa, Sáenz Rotko, José Manuel y Úcar Ventura, Pilar. Traducción e interpretación: estudios, perspectivas y enseñanzas. Madrid: Universidad Pontificia Comillas, 2011.

Rivas Carmona, María del Mar. «La 'visibilidad feminista' de Flora Ossette en su traducción de Woman and Labour de Olive Schreiner». MonTI 3 (2011): 257-287.

Ruiz Mezcua, Aurora. «Hacia una taxonomía de los equipos y sistemas técnicos empleados en la interpretación simultánea». Hikma 10 (2011): 19-158.

SÁenz Rotко, José Manuel. «El doble grado en Relaciones Internacionales y Traducción e Interpretación como opción formativa de futuro». Traducción e interpretación: estudios, perspectivas y enseñanzas. Coord. María Luisa Romana García, José Manuel Sáenz Rotko, Pilar Úcar Ventura. Madrid: Universidad Pontificia Comillas, 2011. 255-268.

SÁnchez Trigo, Elena. «Recursos para la traducción del discurso especializado: ontologías y terminología». Traducción e interpretación: estudios, perspectivas y enseñanzas. Coord. María Luisa Romana García, José Manuel Sáenz Rotko, Pilar Úcar Ventura. Madrid: Universidad Pontificia Comillas, 2011. 269-284.

Santaemilia Ruiz, José. «Woman and translation: Geographies, voices, identities». MonTI 3 (2011): 9-49.

— - Von Flotow, Luise, eds. Mujer y Traducción: geografías, voces e identidades. San Vicente del Raspeig: Publicaciones de la Universidad de Alicante, 2011.

Santiago Vigata, Helena. «Derribando barreras: El uso de subtítulos interlingüísticos en la enseñanza de lenguas». redELE 21 (2011).

Soumani, Katerina. «Property Concepts in Contrast: The Translation of Adjectivals (SpanishEnglish)». Babel afial: Aspectos de filología inglesa y alemana 20 (2011): 103-119.

Talaván Zanón, Noa. «A Quasi-experimental Research Project on Subtitling and Foreign Language Acquisition». Eds. Laura Incalcaterra McLoughlin, Marie Biscio y Márie Áine Ní Mhainnín. Audiovisual Translation: Subtitles and Subtitling. Theory and Practice. Frankfurt: Peter Lang, 2011.

- A University Handbook on Terminology and Specialised Translation. La Coruña: Netbiblo, 2011.

- «La influencia efectiva de los subtítulos en el aprendizaje de lenguas extranjeras: análisis de investigaciones previas». Sendebar 22 (2011): 265-282. 
VAlero Garcés, Carmen. «Ecocriticism and Translation». Odisea: Revista de Estudios Ingleses 12 (2011): 257-272.

- , Bodzer, Anca, Vitalaru, Bianca y Lázaro, Raquel. Traducción e interpretación en los Servicios Públicos en el siglo XXI. Avanzando hacia la unidad en medio de la globalización. Coord. Carmen Valero Garcés. Alcalá de Henares: Universidad de Alcalá de Henares, 2011.

- Traducción e interpretación en los Servicios Públicos en un mundo interconectado. Alcalá de Henares: Universidad de Alcalá de Henares, 2011.

— , Gauthier, Laura, Megdiche, Chiraz y VitAlARU, Bianca. «Traducción, lenguas de la inmigración y recursos online». Hermeneus 13 (2011): 209-232.

- , Lázaro Gutiérrez, Raquel, Vitalaru, Bianca, Bodzer, Anca y Comsa, Aurora. «Experiencias compartidas: Impacto de las nuevas tecnologías en la enseñanza de traducción e interpretación». La creación de espacios comunes de aprendizaje: Experiencias de innovación. Coord. Cristina Canabal García, Dolores García Campos, M. a Isabel Gegúndez Cámara, Carmen Viejo Díaz. Alcalá de Henares: Universidad de Alcalá, 2011. 147-160.

Venuti, Lawrence. «La traducción: entre lo universal y lo local». Tópicos del Seminario 25 (2011): 161-180.

YU, Zhongli. «Gender in Translating Lesbianism in The Second Sex». MonTI 3 (2011): 421-445.

Zaro Vera, Juan Jesús. «Análisis cualitativo y cuantitativo de traducciones literarias: implicaciones didácticas». Traducción e interpretación: estudios, perspectivas y enseñanzas. Coord. María Luisa Romana García, José Manuel Sáenz Rotko, Pilar Úcar Ventura. Madrid: Universidad Pontificia Comillas, 2011. 297-310. 


\title{
F. CULTURA Y CINE
}

\author{
M. ${ }^{a}$ LuZ Arroyo VÁzQuez \\ larroyo@flog.uned.es \\ Antonia Sagredo Santos \\ UNED. Madrid \\ asagredo@ flog.uned.es
}

\section{ÍNDICE}

1. Cultura

2. Cine

\section{Cultura}

Allegue Leira, Alberto. «Irlanda na revista Nós: apuntamentos para un estudo das relacións culturais». Madrygal: Revista de estudios gallegos 13 (2010): 19-28.

Álvarez-Mosquera, Pedro. «Constructing Identity: The Representation of Male Rappers as a Source of Masculinity». Men in Color: Racialized Masculinities in U.S. Literature and Cinema. Ed. Josep M. Armengol. Newscatle upon Tyne: Cambridge Scholars Publishing, 2011. 57-78.

Aponte, Solmerina. «Cultural Materialism and Art of Latinas in New York: Creating a Revolutionary Visual Arts Discourse on Ethnicity, Women's Rights, Exile and the Latino/a Diaspora» Camino real. Cuaderno de Hispanidades Norteamericanas 5 (2011): 11-36.

Ardavín Trabanco, Carlos X., Marí, Jorge, coords. Ventanas sobre el Atlántico: Estados Unidos-España durante el postfranquismo (1975-2008). Biblioteca Javier Coy d'Estudis Nord-Americans. Valencia: Universitat de València, 2011.

ARnson, Cynthia J. «La administración Obama y América Latina: la reconfiguración angustiada». Pensamiento iberoamericano 8 (2011): 23-37.

Arroyo Vázquez, M. ${ }^{a}$ Luz. «El documentalismo social moderno de Dorothea Lange: una reflexión sobre los 'sujetos de la acción' en el mundo rural estadounidense. Revista Internacional de Culturas \& Literaturas 11 (2011): 1-6.

Ashton, Dore. «Lo moderno en el arte americano». Made in USA: arte americano de la Phillips Collection. Coord. Susan Behrends Frank. Madrid: MAPFRE, TF Editores, 2010. 13-22.

Baena Sánchez, Francisco. Una revolución de papel. Prensa y cultura obrera en la colonia británica de las minas de Riotinto, 1913-1920. Sevilla: Centro de Estudios Andaluces, 2011.

Bartolota, Salvatore. «Madonna, Blond Ambition». La Querella de las mujeres en Europa e Hispanoamérica. Eds. Dolores Ramírez Almazán, Milagro Martín Clavijo, Juan Aguilar González y Daniele Cerrato. Sevilla: Arcibel Editores, 2011. 63-87.

Bernárdez Sanchís, Carmen. «Ímpetu y sueño del arte norteamericano en los escritos de Aguilera Cerni». Revista complutense de historia de América 36 (2010): 127-149. 
CARrión, Carmen et al. «Predictors of Attitudes Toward Cosmetic Surgery Among U.S. and Colombian College Women: the Roles of Eating Behaviors and Demographic Variables». Avances en psicología latinoamericana 29. 2 (2011): 276-294.

Caldevilla Domínguez, David. «Las independencias americanas». Historia y Comunicación Social 16 (2011): 13-31.

Cintli RodRiguez, Roberto Dr. «History of Red-Brown Journalism and Communications: Or the Art of Story-Telling». Revista canaria de estudios ingleses 62 (2011): 71-80.

Contreras Villarreal, María del Rosario. La influencia de variables culturales en la construcción del concepto frontera en personas residentes en H. Matamoros, Tamaulipas, México y Brownsville, Texas, Estados Unidos. Tesis doctoral, dir. Mercedes Cubero Pérez, Universidad de Sevilla, 2011, 429 pp.

Cornwell, Bernard. Northumbria, el último reino. Sajones, Vikingos y Normandos. Barcelona: Edhasa, 2011.

De Felipe Martínez, Paula. «Dexter: ironía, cotidianidad y monstruosidad». L'Atalante: revista de estudios cinematográficos 11 (2011): 31-37.

De FiLIPPIS, Daisy Cocco. «Las tertulias de las escritoras dominicanas en Estados Unidos: Una historia». Camino real. Cuaderno de Hispanidades Norteamericanas 4 (2011): 53-71.

De León, Nephtalí.Chican@s: Our Background and Our Pride. Biblioteca Javier Coy d'Estudis Nord-Americans. Valencia: Universitat de València, 2011.

Durán-Almarza, Emilia María. «Chewing English and Spitting Spanish: Josefina Báez Homing Dominican New York». Camino real. Cuaderno de Hispanidades Norteamericanas 4 (2011): 73-94.

ECheVArRía, Ana. «Hacer las Américas». Historia y Vida 524 (2011): 62-69.

Echevarría, Federico. «Made in USA: arte americano en la Phillips Collection». Album, letras, artes 102 (2010): 36-42.

Fernández GiL, María Jesús. «The Holocaust-Memoir Culture in the United States: A Necessary Work of Reparative Justice». A View from the South: Contemporary English and American Studies. Eds. José R. Ibáñez Ibáñez y José Francisco Fernández Sánchez Almería: Editorial Universidad de Almería, 2011.427- 434.

FernándeZ del CAmpo Barbadillo, Eva. «About the Role of India in Contemporary Art». India in the World. Eds. Cristina Gámez-Fernández y Antonia Navarro-Tejero. Newcastle upon Tyne: Cambridge Scholars Publishing, 2011. 233-246.

Frank, Susan Behrends. «Duncan Phillips y The Phillips Collection». Made in USA: arte americano de la Phillips Collection. Coord. Susan Behrends Frank. Madrid: MAPFRE, TF Editores, 2010. 41-64.

Galán García, Agustín, coord. La presencia inglesa en Huelva entre la seducción y el abandono. Sevilla: Universidad Internacional de Andalucía, 2011.

García García, Pedro José. «Lo 'geek' vende. Transformaciones de los 'topoi' sobre el adolescente inadaptado en las series de televisión norteamericanas». Frame: revista de cine de la Biblioteca de la Facultad de Comunicación 7 (2011): 159-190.

- «La ciudad es la protagonista. Construcción de la imagen de Baltimore y Nueva Orleans en The Wire y Treme». Previously on: Estudios interdisciplinarios sobre la ficción televisiva en la Tercera Edad de Oro de la Televisión. Coord. Miguel Angel Pérez Gómez. Sevilla: Biblioteca de la Facultad de Comunicación de la Universidad de Sevilla, 2011. 150-163.

García, Ofelia y Bartlett, Lesley. «Dominican Youth in New York City Schools: A Community Stands Up and Delivers». Camino real. Cuaderno de Hispanidades Norteamericanas 4 (2011): 95-117.

García Martínez, Luis Antonio. «Del modelo de flotas del Adelantado de La Florida Menéndez de Avilés al NCAGS del siglo XXI». Revista General de la Marina 261.1 (2011): 31-41. 
Gómez Fernández, Cristina y Navarro Tejero, Antonia, eds. India in the World. Newcastle upon Tyne: Cambridge Scholars Publishing, 2011.

Gómez Reus, Teresa, ed. ¡Zona prohibida! Mary Borden, una enfermera norteamericana en la Gran Guerra. Biblioteca Javier Coy d'Estudis Nord-Americans. Valencia: Universitat de València, 2011.

González Casademont, Rosa. «Global Irishness Meets Global Culture via The Simpsons». Glocal Ireland: Current Perspectives on Literature and the Visual Arts. Eds. Marisol Morales Ladrón y Juan F. Elices Agudo. Newcastle: Cambridge Scholars Publishing, 2011. 180-199.

González Cruz, María Isabel y Vera Cazorla, María Jesús. «'Strangers in a Strange Land': Mutual Visions of Anglo-Americans and Canarians in the 19th and 20th Centuries». Revista canaria de estudios ingleses 63 (2011): 77-91.

Hernández, Ramona y Stevens-Acevedo, Anthony. «Dominican Studies: A Field on its Own Right». Camino real. Cuaderno de Hispanidades Norteamericanas 4 (2011): 13-17.

Hutchinson, Sydney. «Merengue Típico in New York City: A History». Camino real. Cuaderno de Hispanidades Norteamericanas 4 (2011): 119-141.

JASPE, Alvaro. «Ireland and Spain 1931-1933: Divergent Republics». Estudios Irlandeses 6 (2011): 8-20.

Jiménez-Blanco Carrillo de Albornoz, María Dolores. «El fértil desvío de la norma». Made in USA: arte americano de la Phillips Collection. Coord. Susan Behrends Frank. Madrid: MAPFRE, TF Editores, 2010. 23-40.

Juan Rubio, Antonio Daniel. «Frances Perkins: A Life of Commitment». Feminismo /s: Revista del Centro de Estudios sobre la Mujer de la Universidad de Alicante 16 (2010): 159-179.

- «Ecos de la época del Jazz en los Estados Unidos». Tonos digital: Revista electrónica de estudios filológicos 20 (2010). Revista electrónica.

Kagan, Richard L. «The Spanish 'Craze' in the United States: Cultural Entitlement and the Appropriation of Spain's Cultural Patrimony, ca.1890-ca.1930». Revista complutense de historia de América 36 (2010): 37-58.

LeE, Euna. «Pancho Villa y su resonancia en el paradigma fronterizo». Estudios sobre las culturas contemporáneas 34 (2011): 109-135.

Luque Silvestre, Joan Carles y Junqueras I Vies, Oriol. «La batalla del Atlántico». Historia y Vida 524 (2011): 70-77.

Manzanas, Ana M. ${ }^{\mathrm{a}}$ y Benito, Jesús. Cities, Borders and Spaces in Intercultural American Literature and Film. Nueva York: Routledge, 2011.

Mercereau, Jean. «From 'Criminal Adventurer' to 'the Most Important Irishman of Our Time': the Irish Times and Eamon de Valera, 1916-1973». Estudios Irlandeses 6 (2011): 70-82.

Martín Alegre, Sara. «Shades of Evil: The Construction of White Patriarchal Villainy in the Star Wars Saga». Men in Color: Racialized Masculinities in U.S. Literature and Cinema. Ed. Josep M. Armengol. Newscatle upon Tyne: Cambridge Scholars Publishing, 2011. 143-168.

— «Unstable Meanings, Unstable Methods: Analysing Linkin Parks's song 'What I've done'». A View from the South: Contemporary English and American Studies. Eds. José R. Ibáñez Ibáñez y José Francisco Fernández Sánchez Almería: Editorial Universidad de Almería, 2011. 150-157.

Martín-Lucas, Belén. «Burning Down the Little House on the Praire: Asian Pioneers in Contemporary North America». Atlantis. Journal of the Spanish Association of AngloAmerican Studies 33.2 (2011): 27-41.

Martín NÚÑEZ, Marta. «House: la estructura narrativa al servicio de la ciencia». L'Atalante: revista de estudios cinematográficos 11 (2011): 26-30.

Martínez-Cabeza, Miguel A. «Adaptation in the Arena: South African Politics at the Movies». A View from the South: Contemporary English and American Studies. Eds. José R. Ibáñez Ibáñez y José Francisco Fernández Sánchez Almería: Editorial Universidad de Almería, 2011. 194-200. 
MÉndez, Danny. «Culture and the City: Pedro Henríquez Ureña's New York City». Camino real. Cuaderno de Hispanidades Norteamericanas 4 (2011): 143-168.

Morales, Marisol y Elices Agudo Juan F., eds. Glocal Ireland: Current Perspectives on Literature and the Visual Arts. Newcastle upon Tyne: Cambridge Scholars Publishing, 2011.

Muñoz Sempere, Daniel y Alonso, Gregorio, eds. Londres y el liberalismo hispánico. Madrid/ Frankfurt: Iberoamericana/Verveuert, 2011.

Navarro Romero, Betsabé. «British Identity and Political Discourse: New Labour, New Britain? A View from the South: Contemporary English and American Studies. Eds. José R. Ibáñez Ibáñez y José Francisco Fernández Sánchez Almería: Editorial Universidad de Almería, 2011. 158-164.

Oria Gómez, Beatriz. "'Living in Reality Means Living in Pain, Fear, or Brooklyn': the Representation of New York in Sex and the City». Odisea: Revista de Estudios Ingleses 12 (2011): 165-182.

PAcheco Costa, Verónica. «La querella de las mujeres en el teatro británico: las sufragistas». La querella de las mujeres en Europa e Hispanoamérica. Eds. Dolores Ramírez Almazán, Milagro Martín Clavijo, Juan Aguilar González y Daniele Cerrato. Sevilla: Arcibel Editores, 2011. 77-92.

Pérez Vigil, Luis V. «La 'nueva' política nuclear militar de los Estados Unidos». Revista General de la Marina 260.1 (2011): 31-35.

Phillipson, Robert. «Americanización e inglesización como procesos de ocupación global». Discurso \& Sociedad 5.1 (2011): 96-131.

Piñeiro Otero, María Teresa. «Heroes, filibusteros y villanos. Representaciones y mitos de la Guerra de Cuba en la prensa gallega del momento (1895-1898)». Historia y Comunicación Social 16 (2011): 111-130.

Powell, Charles. El amigo americano. España y Estados Unidos: de la Dictadura a la democracia. Madrid: Editorial Galaxia Gutemberg/Círculo de Lectores, 2011.

REVERT, Jordi «Los Soprano en cinco tiempos: o cómo aprendí a dejar de preocuparme y empezar a amar al gángster». L'Atalante: revista de estudios cinematográficos 11 (2011): 5-11.

Rockland, Michael A. Reminiscences of Spain. Biblioteca Javier Coy d'Estudis Nord-Americans. Valencia: Universitat de València, 2011.

- Un diplomático americano en la España de Franco. Biblioteca Javier Coy d'Estudis NordAmericans. Valencia: Universitat de València, 2011.

Rodríguez Moreno, José Joaquín «La energía atómica vista a través de la cultura popular estadounidense: una aproximación». Investigaciones históricas: Época moderna y contemporánea 31 (2011): 165-200.

Rodríguez Ramírez, María del Carmen. «A Store of the Boy Meets the Girl: (Unbroken) Romantic Conventions in (500) Days of Summer». A View from the South: Contemporary English and American Studies. Eds. José R. Ibáñez Ibáñez y José Francisco Fernández Sánchez Almería: Editorial Universidad de Almería, 2011. 201-206.

Roett, Riordan. «Estados Unidos y América Latina en el siglo xxi». Pensamiento Iberoamericano 8 (2011): 57-69.

Rollason, Christopher. «'Lorca Graves': presencias de la literatura hispana en la obra de Bob Dylan». The Grove: Working Papers on English Studies 18 (2011): 165-186.

Romero Ruiz, M. ${ }^{a}$ Isabel. «Gender Policy, the London Lock Asylum Committee (1836-1842) and the Asylum Regulations for 1840». Atlantis. Journal of the Spanish Association of AngloAmerican Studies 33.2 (2011): 123-136.

- y Castro Borrego, Silvia Pilar, eds. Cultural Migrations and Gendered Subjects: Colonial and Postcolonial Representations of the Female Body. Newcastle upon Tyne: Cambridge Scholars Publishing, 2011.

Romero Ruiz, Maria Isabel. «Women's Identity and Migration: Stead's Articles in the Pall Mall Gazette on Prostitution and White Slavery». Cultural Migrations and Gendered Subjects: 
Colonial and Postcolonial Representations of the Female Body. Eds. Silvia Castro Borrego y María Isabel Romero Ruiz. Newcastle upon Tyne: Cambridge Scholars Publishing, 2011. 27-54. Rosende Pérez, Aída. «Beyond the Local and the Global: 'Bodies that Matter' in Amanda Coogan's Visual Practice». Glocal Ireland: Current Perspectives on Literature and the Visual Arts. Eds. Marisol Morales Ladrón y Juan F. Elices Agudo. Newcastle upon Tyne: Cambridge Scholars Publishing, 2011. 229-242.

Royo Grasa, María del Pilar. «Border Jam session: the Transnational Subject of the Visitor». A View from the South: Contemporary English and American Studies. Eds. José R. Ibáñez Ibáñez y José Francisco Fernández Sánchez Almería: Editorial Universidad de Almería, 2011. 207-212.

Rubio Alcocer, Agustín. «Carbon-copy de los años cuerdos: a propósito de Mad Men». L'Atalante: revista de estudios cinematográficos 11 (2011): 12-18.

SAgredo Santos, Antonia. «Las promotoras de los derechos de la mujer en los EE.UU: el congreso de 'Seneca Falls' como legado de la querella de las mujeres en América». La querella de las mujeres en Europa e Hispanoamérica. Eds. Dolores Ramírez Almazán, Milagro Martín Clavijo, Juan Aguilar González y Daniele Cerrato. Sevilla: Arcibel Editores, 2011. 291-309.

Salas Franco, M. ${ }^{a}$ Pilar, ed. Salvad España, salvad la paz. Memoriales de la Guerra Civil Española en el Reino Unido e Irlanda. Logroño: Editorial Siníndice, 2011.

Sánchez Moreno, Francisco Javier. «El cautivo y su instrumentalización en las relaciones fronterizas tras el Tratado de Guadalupe-Hidalgo». Anuario de Estudios Americanos 69.1 (2011): 51-72.

Seco González, Carlos. «El Celtic FC y la expresión del republicanismo a través de los cánticos de fútbol». Oceánide 3 (2011). Revista electrónica.

Seguro Gómez, María Isabel. «Representing Irishness in The Crying Game». A View from the South: Contemporary English and American Studies. Eds. José R. Ibáñez Ibáñez y José Francisco Fernández Sánchez Almería: Editorial Universidad de Almería, 2011. 213-218.

Serra Pagés, Carles Conrad. «'Hospitality' and Postcolonial Australia». A View from the South: Contemporary English and American Studies. Eds. José R. Ibáñez Ibáñez y José Francisco Fernández Sánchez Almería: Editorial Universidad de Almería, 2011. 300-306.

Serrano Lanzuela, Carmina. «Comparing F. D. Roosevelt and B. H. Obama in Developing Welfare». Revista de Estudios Norteamericanos 15 (2011): 101-121.

Sorrache Cuerva, Miguel y Ortega Santos, Antonio, coords. El patrimonio cultural en las misiones de la Baja California Sur. Granada: Atrio, 2011.

Tноми́s, Joan Maria. La batalla del Wolframio. Barcelona: Cátedra, 2011.

- Roosevelt, Franco and the End of the Second World War. Nueva York: Palgrave MacMillan, 2011.

Yuste González, Javier. «Women Accepted for Volunteer Emergency Service». Revista General de la Marina 261.1 (2011): 21-29.

\section{CINE}

Alcoriza Javier y Romero Escrivá, Rebeca. «El ala oeste de la Casa Blanca y la psicología de la democracia». L'Atalante: revista de estudios cinematográficos 11 (2011): 44-51.

Alvarez Gila, Oscar. «Glory (1989): Una visión dramatizada sobre el origen de los Buffalo Soldiers». La historia a través del cine: Estados Unidos, una mirada a su imaginario colectivo. Ed. Coro Rubio Pobes. Zarautz: Servicio de Publicaciones de la Universidad del País Vasco, 2010. 19-50. 
Armengol, Josep M. Men in color: racialized masculinities in U. S. Literature and Cinema. Newcastle upon Tyne: Cambridge Scholars Publishing, 2011.

Barros Grela, Eduardo. «Visualidades queer en los estudios culturales: cine subalterno y New York, la ciudad permeable». The Grove: Working Papers on English Studies 18 (2011): 187-198.

Bort Gual, Iván. «Narrativa a la deriva: de Perdidos a la eternidad». L'Atalante: Revista de estudios cinematográficos 11 (2011): 52-59.

— et al. «Big Love: el 'travelling lícito'». L'Atalante: revista de estudios cinematográficos 11 (2011): 19-25.

Bosch SÁnchez, M. Aurora. «Los violentos años veinte: Gánsters, prohibición y cambios sociopolíticos en el primer tercio del siglo xx en Estados Unidos». La historia a través del cine: Estados Unidos, una mirada a su imaginario colectivo. Ed. Coro Rubio Pobes. Zarautz: Servicio de Publicaciones de la Universidad del País Vasco, 2010. 51-82.

Calvo Herrera, Concepción. «Producción, distribución y administración del cine americano: formar públicos para el cine español». Telos: Cuadernos de comunicación e innovación 88 (2011): 9-11.

Carmona, Luis Miguel. Interpretes del Western. Madrid: Cacitel, 2011.

CAsas, Quim. «John Ford, Wallace Berry y la bonhomía». Dirigido por .... Revista de cine 411 (2011): 78-79.

De La Guardia Herrero, Carmen. «Diásporas culturales: los republicanos españoles y la transformación del hispanismo estadounidense». Mirada hispánica 1 (2010): 117-128.

— «Republicanismo, género y esclavitud: El viaje transatlántico de Sarah Livingston Jay y de su esclava Abbe (1779-1783)».

- Arenal: Revista de historia de mujeres 18.1 (2011): 117-146.

Díaz Barrado, Mario Pedro. «My Family (Mi familia)». La historia a través del cine: Estados Unidos, una mirada a su imaginario colectivo. Ed. Coro Rubio Pobes. Zarautz: Servicio de Publicaciones de la Universidad del País Vasco, 2010. 191-222.

Fernández Valentí, Tomás. «Dejando atrás la América profunda». Dirigido por ...: Revista de cine 413 (2011): 32-33.

Flores Juberías, Carlos. «Cine y elecciones: El candidato como paradigma del género». La historia a través del cine: Estados Unidos, una mirada a su imaginario colectivo. Ed. Coro Rubio Pobes. Zarautz: Servicio de Publicaciones de la Universidad del País Vasco, 2010. 125-156.

FRESNEDA, I. «Lars von Trier y Bailar en la oscuridad: ¿lo hemos visto todo ya en el cine?». La historia a través del cine: Estados Unidos, una mirada a su imaginario colectivo. Ed. Coro Rubio Pobes. Zarautz: Servicio de Publicaciones de la Universidad del País Vasco, 2010. 223-240.

García Periago, Rosa M. ${ }^{a}$ "Quitting India, Quitting Shakespeare? The Curious Case of 1942: A Love Story». A View from the South: Contemporary English and American Studies. Eds. José R. Ibáñez Ibáñez y José Francisco Fernández Sánchez Almería: Editorial Universidad de Almería, 2011. 252-257.

GARrido Hornos, M. ${ }^{a}$ Carmen. «Hacia el concepto hitchcockiano de feminidad: inmoralidad y desigualdad en las mujeres del cine de suspense». Espéculo. Revista de Estudios Literarios 47 (2011). Revista electrónica.

Gómez TARín, Francisco Javier. «'Generación Kill': la estética de la muerte». L’Atalante: revista de estudios cinematográficos 11 (2011): 38-43.

González López, Jesús A. «In Search of a Third Dimension: Paul Auster's Films from Smoke to The Book of Illusions». The Invention of Illusions: International Perspectives on Paul Auster. Eds. Stefania Ciocia y Jesús González López. Newcastle upon Tyne: Cambridge Scholars Publishing, 2011. 193-218. 
González, Jesús A. y Stefania, eds. The Invention of Illusions: International Perspectives on Paul Auster. Newcastle upon Tyne: Cambridge Scholars Publishing, 2011.

Guijarro González, Juan Ignacio. «Film and Chicano I/dentity in Tino Villanueva's Scene from the Movie GIANT». Beyond the Myth: New Perspectives on Western Texts. Eds. David Rio, Amaia Ibarraran y Martin Simonson. Londres: Portal, 2011. 157-176.

Herráiz Ripio, Alejandro. Actores de primera. Estrellas de segunda: Los grandes secundarios del cine norteamericano. Madrid: T\&B Editores, 2011.

Hurtado, José Antonio. «El francés que amaba el cine americano». François Truffaut: el deseo del cine. Coord. Carlos Losilla Alcalde. San Sebastián: Donostia Kultura, 2010. 89-100.

IgLesias Díaz, Guillermo. «Beyond the Reality/Fiction Game: An/Other Way of Exploring Contemporary Ireland in Film». Glocal Ireland: Current Perspectives on Literature and the Visual Arts. Eds. Marisol Morales Ladrón y Juan F. Elices Agudo. Newcastle upon Tyne: Cambridge Scholars Publishing, 2011. 200-213.

Lerman, Gabriel. «Entrevista con Joel \& Ethan Coen: 'No sé si estábamos pensando en hacer un western cuando nos interesamos en Valor de Ley'». Dirigido por .... Revista de cine 408 (2011): 26-29.

Losilla, Carlos. En tránsito. Berlín-París-Hollywood. Más allá de la historia del cine. Madrid: T \& B Editores, 2010.

Martín PÁRraga, Javier. «De Caperucita Roja a las slasher movies: reescrituras del cuento tradicional en la ficción cinematográfica norteamericana». Extravío. Revista electrónica de literatura comparada 6 (2011): 69-81.

- «El cine de terror norteamericano de los 40 y 50 como instrumento de propaganda anticomunista». Espéculo. Revista de Estudios Literarios 46 (2010-11). Revista electrónica.

Martínez Martínez, Elisa María. Hitchkock: imágenes entre líneas. Biblioteca Javier Coy d'Estudis Nord-Americans. Valencia: Universitat de València, 2011.

Martin Renes, Cornelis. «Wrestling with the Odds in Once Were Warriors: Alan Tamahori's Cinematic Adaptation». Miscelánea: A Journal of English and American Studies 44 (2011): 87-106.

Melús, Eva. «Mae West contra todo». Historia y Vida 524 (2011): 60-67.

Memba González, Javier. Nueva era del cine de ciencia-ficción. Madrid: T \& B Editores, 2011. Meyers, Jeffrey. Gary Cooper: El héroe americano. Madrid: T \& B Editores, 2011.

Navarro, Antonio José, «Bailando en la oscuridad: Cisne negro, Darren Aronofsky». Dirigido por ....: Revista de cine 407 (2011): 26-31.

— «Los extraterrestres invaden el 'Far West'». Dirigido por .... Revista de cine 414 (2011): 24-25.

— «La oscura lucha por la supervivencia: 127 horas». Dirigido por .... Revista de cine 408 (2011): 38-39.

— «Pensar en la muerte: Más allá de la vida, Clint Eastwood». Dirigido por .... Revista de cine 407 (2011): 22-25.

— «Romanos en Britania: La Legión del águila, Kevin Macdonald». Dirigido por .... Revista de cine 410 (2011): 32-33.

Palacios Martín, Jesús. Neonoir:el cine negro norteamericano moderno. Madrid: T\&B Editores, 2011.

Pérez Rufí, José Patricio. «Estereotipos y cine de género en Kubrick». Espéculo. Revista de Estudios Literarios 46 (2010-11). Revista electrónica.

- «Narrativa cinematográfica clásica y mujer en la comedia clásica de Howard Hawks». Espéculo. Revista de Estudios Literarios 47 (2011). Revista electrónica.

Pedrero Santos, Juan Andrés. Cine al rojo vivo: Las películas que impactaron al mundo (19191972). Madrid: T\&B Editores, 2011.

Prieto Martínez, Miguel Angel. Un paseo por el lado oscuro de Hollywood: Vivir y morir en Los Ángeles. Madrid: T\&B Editores, 2010. 
Redondo Sánchez, Carlos. «Expiación, de la novela al film». 1616. Anuario de la Sociedad Española de Literatura General y Comparada 1 (2011): 307-324.

Romero Escrivá, Rebeca. «Migraciones: Las uvas de la ira y los objetivos de la Farm Security Administration». L'Atalante: revista de estudios cinematográficos 12 (2011): 30-41.

Rubio García, Mónica y LOUVISH, Simón. La doble vida de Laurel y Hardy: las raíces de la comedia. Madrid: T\&B Editores, 2010.

Rubio Pobes, Coro. «La 'diplomacia atómica' en la Guerra Fría y Estados Unidos: ¿Teléfono Rojo? Volamos hacia Moscú». La historia a través del cine: Estados Unidos, una mirada a su imaginario colectivo. Ed. Coro Rubio Pobes. Zarautz: Servicio de Publicaciones de la Universidad del País Vasco, 2010. 157-190.

— «Estados Unidos: Un recorrido por su historia a través del cine de ficción». La historia a través del cine: Estados Unidos, una mirada a su imaginario colectivo. Ed. Coro Rubio Pobes. Zarautz: Servicio de Publicaciones de la Universidad del País Vasco, 2010. 241-274.

- , ed. La historia a través del cine: Estados Unidos, una mirada a su imaginario colectivo. Zarautz: Servicio de Publicaciones de la Universidad del País Vasco, 2010.

SAla, Angel. «El Oeste que nunca estuvo allí: Valor de ley». Dirigido por ....: Revista de cine 408 (2011): 22-25.

SÁNCHEZ NoRIEGA, José Luis. «El manantial, una apología del individualismo norteamericano». La historia a través del cine: Estados Unidos, una mirada a su imaginario colectivo. Ed. Coro Rubio Pobes. Zarautz: Servicio de Publicaciones de la Universidad del País Vasco, 2010. 111-124.

- «Riambau, E. Hollywood en la era digital. De Jurassic Park a Avatar». Quaderns del CAC 37 (2011): 141-142.

SANDERSON, John D. «The Shadow over Galicia: H. P. Lovecraft's Obsessions Resurface in the Film Adaptation of Dagon (2001)». Odisea: Revista de Estudios Ingleses 12 (2011): 245-256.

Santos Moya, Esperanza. «Bollywood and South Asian Diasporic Films in the U.K.: Gurinder Chadha's Female Road Movie». India in the World. Eds. Cristina Gámez-Fernández y Antonia Navarro-Tejero. Newcastle upon Tyne: Cambridge Scholars Publishing, 2011. 265-276.

Sutton, Damian. «Time-lapse, time map'. El cuerpo fotográfico de San Francisco en Zodiac de David Fincher». L'Atalante: revista de estudios cinematográficos 12 (2011): 7-13.

Tejero García-Tejero, Juan. Audrey Hepburn: Una princesa en la corte de Hollywood. Madrid: T \& B Editories, 2010.

- Qué Ruina de película.: Los grandes fiascos del Nuevo Hollywood. Madrid: T \& B Editores, 2010. Torrado Mariñas, Laura. «Dr Strangelove, or How I Learned to Read Kubrick's Conceptual Universe». ES: Revista de Filología Inglesa 32 (2011): 331-344.

Tracy, Tony, ed. «Irish Film and Television - 2010». Estudios Irlandeses 6 (2011): 191-224.

VAN Der VART, Yannick. Rodamos Historia. Madrid: T \& B Editores, 2010.

Vericat Turá, David. Silencio, se habla. El cine según sus directores. Madrid: T \& B Editores, 2010.

Vidal Pelaz, José. «La crisis de la democracia en América: Caballero sin espada (Frank Capra, 1939)». La historia a través del cine: Estados Unidos, una mirada a su imaginario colectivo. Ed. Coro Rubio Pobes. Zarautz: Servicio de Publicaciones de la Universidad del País Vasco, 2010. 83-110.

VogelaAR, Alison. «Goracle's Travels: En-Visioning Global Communities for Climate Change in An Inconvenient Truth». Cultura, lenguaje y representación (Culture, Language and Representation) 9 (2011): 225-244. 